University of Nebraska - Lincoln

DigitalCommons@University of Nebraska - Lincoln

\title{
FLUXNET: A New Tool to Study the Temporal and Spatial Variability of Ecosystem-Scale Carbon Dioxide, Water Vapor, and Energy Flux Densities
}

\author{
Dennis Baldocchi \\ University of California, Berkeley \\ Eva Falge \\ Universitat Bayreuth, Bayreuth \\ Lianhong Gu \\ University of California, Berkeley \\ Richard Olson \\ Oak Ridge National Laboratory \\ David Hollinger \\ USDA Forest Service, Durham
}

Follow this and additional works at: https://digitalcommons.unl.edu/natrespapers

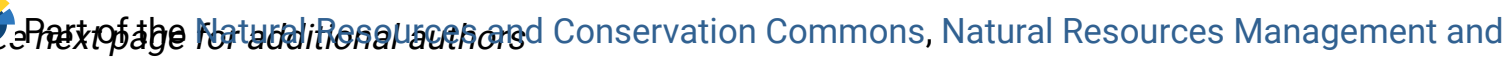
Policy Commons, and the Other Environmental Sciences Commons

Baldocchi, Dennis; Falge, Eva; Gu, Lianhong; Olson, Richard; Hollinger, David; Running, Steve; Anthoni, Peter; Bernhofer, Ch.; Davis, Kenneth; Evans, Robert; Fuente, Jose; Goldstein, Allen; Katul, Gabriel; Law, Beverly; Lee, Xuhui; Malhi, Yadvinder; Meyers, Tilden; Munge, William; Oechel, Walt; U, K.T. Paw; Pilegaard, Kim; Schmid, H.P.; Valentini, Riccardo; Verma, Shashi; Vesala, Timo; Wilson, Kell; and Wofsy, Steve, "FLUXNET: A New Tool to Study the Temporal and Spatial Variability of Ecosystem-Scale Carbon Dioxide, Water Vapor, and Energy Flux Densities" (2001). Papers in Natural Resources. 1163.

https://digitalcommons.unl.edu/natrespapers/1163

This Article is brought to you for free and open access by the Natural Resources, School of at DigitalCommons@University of Nebraska - Lincoln. It has been accepted for inclusion in Papers in Natural Resources by an authorized administrator of DigitalCommons@University of Nebraska - Lincoln. 


\section{Authors}

Dennis Baldocchi, Eva Falge, Lianhong Gu, Richard Olson, David Hollinger, Steve Running, Peter Anthoni, Ch. Bernhofer, Kenneth Davis, Robert Evans, Jose Fuente, Allen Goldstein, Gabriel Katul, Beverly Law, Xuhui Lee, Yadvinder Malhi, Tilden Meyers, William Munge, Walt Oechel, K.T. Paw U, Kim Pilegaard, H.P. Schmid, Riccardo Valentini, Shashi Verma, Timo Vesala, Kell Wilson, and Steve Wofsy 


\title{
FLUXNET: A New Tool to Study the Temporal and Spatial Variability of Ecosystem-Scale Carbon Dioxide, Water Vapor, and Energy Flux Densities
}

\author{
Dennis Baldocchi, ${ }^{a}$ Eva Falge, ${ }^{\mathrm{b}}$ Lianhong Gu, ${ }^{\mathrm{a}}$ Richard Olson, ${ }^{\mathrm{c}}$ David Hollinger, ${ }^{\mathrm{d}}$ Steve Running, \\ Peter Anthoni, ${ }^{f}$ Ch. Bernhofer, ${ }^{,}$Kenneth Davis, ${ }^{\text {h }}$ Robert Evans, ${ }^{d}$ Jose Fuentes, ${ }^{,}$Allen Goldstein, ${ }^{a}$ \\ Gabriel Katul,, Beverly Law, ${ }^{f}$ Xuhui Lee, ${ }^{\mathrm{k}}$ Yadvinder Malhi,' Tilden Meyers, ${ }^{\mathrm{m}}$ William Munger, ${ }^{\mathrm{n}}$ \\ Walt Oechel, ${ }^{\circ}$ K. T. Paw U, ${ }^{p}$ Kim Pilegaard, ${ }^{q}$ H. P. Schmid, ${ }^{r}$ Riccardo Valentini, ${ }^{\mathrm{s}}$ \\ Shashi Verma, ${ }^{t}$ Timo Vesala, ${ }^{,}$Kell Wilson, ${ }^{\mathrm{m}}$ and Steve Wofsy ${ }^{\mathrm{n}}$
}

\begin{abstract}
FLUXNET is a global network of micrometeorological flux measurement sites that measure the exchanges of carbon dioxide, water vapor, and energy between the biosphere and atmosphere. At present over 140 sites are operating on a long-term and continuous basis. Vegetation under study includes temperate conifer and broadleaved (deciduous and evergreen) forests, tropical and boreal forests, crops, grasslands, chaparral, wetlands, and tundra. Sites exist on five continents and their latitudinal distribution ranges from $70^{\circ} \mathrm{N}$ to $30^{\circ} \mathrm{S}$.

FLUXNET has several primary functions. First, it provides infrastructure for compiling, archiving, and distributing carbon, water, and energy flux measurement, and meteorological, plant, and soil data to the science community. (Data and site information are available online at the FLUXNET Web site, http://www-eosdis.ornl.gov/FLUXNET/.) Second, the project supports calibration and flux intercomparison activities. This activity ensures that data from the regional networks are intercomparable. And third, FLUXNET supports the synthesis, discussion, and communication of ideas and data by supporting project scientists, workshops, and visiting scientists. The overarching goal is to provide information for validating computations of net primary productivity, evaporation, and energy absorption that are being generated by sensors mounted on the NASA Terra satellite.

Data being compiled by FLUXNET are being used to quantify and compare magnitudes and dynamics of annual ecosystem carbon and water balances, to quantify the response of stand-scale carbon dioxide and water vapor flux densities to controlling biotic and abiotic factors, and to validate a hierarchy of soil-plant-atmosphere trace gas exchange models. Findings so far include 1) net $\mathrm{CO}_{2}$ exchange of temperate broadleaved forests increases by about $5.7 \mathrm{~g} \mathrm{C} \mathrm{m}^{-2}$ day $^{-1}$ for each additional day that the growing season is extended; 2) the sensitivity of net ecosystem $\mathrm{CO}_{2}$ exchange to sunlight doubles if the sky is cloudy rather than clear; 3) the spectrum of $\mathrm{CO}_{2}$ flux density exhibits peaks at timescales of days, weeks, and years, and a spectral gap exists at the month timescale; 4) the optimal temperature of net $\mathrm{CO}_{2}$ exchange varies with mean summer temperature; and 5) stand age affects carbon dioxide and water vapor flux densities.
\end{abstract}

\footnotetext{
aESPM, University of California, Berkeley, Berkeley, California. 'Pflanzenökologie, Universität Bayreuth, Bayreuth, Germany. 'Environmental Science Division, Oak Ridge National Laboratory, Oak Ridge, Tennessee.

'USDA Forest Service, Durham, New Hampshire.

'School of Forestry, University of Montana, Missoula, Montana.

'Richardson Hall, Oregon State University, Corvallis, Oregon.

${ }^{\text {g} T e c h n i s c h e ~ U n i v e r s i t a ̈ t ~ D r e s d e n, ~ I H M ~ M e t e o r o l o g i e, ~ T h a r a n d t, ~ G e r m a n y . ~}$ "Department of Meteorology, The Pennsylvania State University, University Park, Pennsylvania.

iDepartment of Environmental Science, University of Virginia, Charlottesville, Virginia.

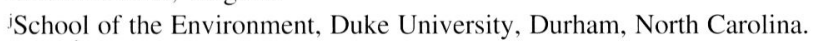
${ }^{\mathrm{k}}$ School of Forestry, Yale University, New Haven, Connecticut. 'Institute of Ecology and Resource Management, University of Edinburgh, Edinburgh, United Kingdom.

mOAA/Atmospheric Turbulence and Diffusion Division, Oak Ridge, Tennessee.
}

"Department of Earth and Planetary Sciences, Harvard University, Cambridge, Massachusetts.

${ }^{\circ}$ Department of Biology, San Diego State University, San Diego, California. 'Land, Air and Water Resources, University of California, Davis, Davis, California.

${ }^{q}$ Plant Biology and Biogeochemistry Department, Risoe National Laboratory, Roskilde, Denmark.

'Department of Geography, Indiana University, Bloomington, Indiana. 'DISAFRI, Universita de Tuscia, Viterbo, Italy.

'School of Natural Resource Sciences, University of Nebraska at Lincoln, Lincoln, Nebraska.

"Department of Physics, University of Helsinki, Helsinki, Finland.

Corresponding author address: Dennis Baldocchi, Department of Environmental Science, Policy and Management, Ecosystems Science Division, 151 Hilgard Hall, University of California, Berkeley, Berkeley, CA 94720. E-mail: baldocchi@nature.berkeley.edu

In final form 27 February 2001.

(C)2001 American Meteorological Society 


\section{Introduction}

Large-scale, multi-investigator projects have been the keystone of many scientific and technological advances in the twentieth century. Physicists have learned much about the structure of an atom's nucleus with particle accelerators. Astrophysicists now peer deep into space with the Hubble Space Telescope and an array of radio telescopes. Molecular biologists are decoding the structure of our DNA with the Human Genome project.

Ecosystem scientists need a tool that assesses the flows of carbon, water, and energy to and from the terrestrial biosphere across the spectrum of time- and space scales over which the biosphere operates (see Running et al. 1999; Canadell et al. 2000). Similarly, atmospheric scientists need a tool to quantify surface energy fluxes at the land-atmosphere interface, as these energy fluxes influence weather and climate (Betts et al. 1996; Pielke et al. 1998). In this paper, we report on such a tool. It consists of a global array of micrometeorological towers that are measuring flux densities of carbon dioxide, water vapor, and energy between vegetation and the atmosphere on a quasicontinuous and long-term (multiyear) basis. The objectives of this paper are to introduce the FLUXNET project and describe its rationale, goals, measurement methods, and geographic distribution. We also present a sampling of new results that are being generated through the project. The intent is to show how information from this network can aid ecologists, meteorologists, hydrologists, and biogeochemists to understand temporal and spatial variations that are associated with fluxes of carbon and water between the biosphere and atmosphere.

\section{What is the problem?}

Over the past century, the states of the earth's atmosphere and biosphere have experienced much change. Since the dawn of the industrial revolution, the mean global $\mathrm{CO}_{2}$ concentration has risen from about 280 ppm to over 368 ppm (Keeling and Whorf 1994; Conway et al. 1994). The secular rise in atmospheric carbon dioxide concentrations is occurring due to imbalances between the rates that anthropogenic and natural sources emit $\mathrm{CO}_{2}$ and the rate that biospheric and oceanic sinks remove $\mathrm{CO}_{2}$ from the atmosphere. Superimposed on the secular trend of $\mathrm{CO}_{2}$ is a record of large interannual variability in the annual rate of growth of atmospheric $\mathrm{CO}_{2}$. Typical values of interannual variability are on the order of $0.5-3.0 \mathrm{ppm} \mathrm{yr}^{-1}$. On a mass basis, these values correspond with a range

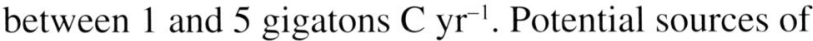
year-to-year changes in atmospheric $\mathrm{CO}_{2}$ remain a topic of debate. Studies of atmospheric ${ }^{13} \mathrm{C}^{2}$ and $\mathrm{O}_{2}$ distributions imply that the terrestrial biosphere plays an important role in this interannual variability (Ciais et al. 1995; Keeling et al. 1996). Sources of this variability have been attributed to El Niño/La Niña events, which cause regions of droughts or superabundant rainfall (Conway et al. 1994; Keeling et al. 1995), and alterations in the timing and length of the growing season (Myneni et al. 1997a,b; Randerson et al. 1997).

Rising levels of $\mathrm{CO}_{2}$, and other greenhouse gases, are of concern to scientists and policy makers because they trap infrared radiation that is emitted by the earth's surface. Potential consequences of elevated $\mathrm{CO}_{2}$ concentrations include a warming of the earth's surface (Hansen et al. 1998), melting of polar icecaps and a rising sea level, and an alteration of plant and ecosystem physiological functioning and plant composition (Amthor 1995; Norby et al. 1999).

With regard to plants and ecosystems, short-term experiments with elevated $\mathrm{CO}_{2}$ show increased rates of photosynthesis and plant growth and lowered stomatal conductance (Drake et al. 1996). The long-term sustainability of enhanced rates of growth by plants, however, depends on nutrient and water availability, temperature, and light competition (Ceulemans and Mousseau 1994; Norby et al. 1999). Warmer temperatures, associated with elevated $\mathrm{CO}_{2}$, promote increased rates of respiration when soil moisture is ample. But if climate warming is associated with drying, there can be reduced assimilation and lower rates of soil/root respiration in temperate ecosystems. In the tundra and boreal forest, warming and drying can lower water tables, exposing organic peat to air and increasing its rate of respiration (Goulden et al. 1998; Lindroth et al. 1998; Oechel et al. 2000).

How evaporation is impacted by elevated $\mathrm{CO}_{2} \mathrm{de}$ pends on the scale of study and concurrent changes in leaf area index, canopy surface conductance, and the depth of the planetary boundary layer. Theory indicates that complex feedbacks among stomatal conductance, leaf temperature, and the air's vapor pressure deficit cause responses at the leaf scale to differ from that of the canopy scale. For instance, a potential reduction of leaf transpiration, by stomatal closure, is compensated for in part by the entrainment of dry air from above the planetary boundary layer and elevated 
leaf temperatures and humidities (Jacobs and deBruin 1992). Hence, canopy evaporation may not be reduced to the same degree as leaf transpiration in an elevated $\mathrm{CO}_{2}$ world.

In the meantime, the composition of the land surface has changed dramatically to meet the needs of the growing human population. Many agricultural lands have been transformed into suburban and urban landscapes, wetlands have been drained, and many tropical forests have been logged, burnt, and converted to pasture. In contrast, abandoned farmland in the northeast United States and Europe is returning to forest as those societies become more urban. Changes in land use alter the earth's radiation balance by changing its albedo, Bowen ratio (the ratio between the flux densities of sensible and latent heat exchange), leaf area index, and physiological capacity to assimilate carbon and evaporate water (Betts et al. 1996; Pielke et al. 1998). Changing a landscape from forest to agricultural crops, for instance, increases the surface's albedo and decreases the Bowen ratio (Betts et al. 1996); forests have a lower physiological capacity to assimilate carbon and a lower ability to transpire water, as compared to crops (Kelliher et al. 1995; Baldocchi and Meyers 1998). A change in the age structure of forests due to direct (deforestation) or indirect (climateinduced fires) disturbance alters its ability to acquire carbon and transpire water (Amiro et al. 1999; Schulze et al. 1999).

The issues identified above all require information on fluxes of carbon, water, and energy at the earth's surface and how these fluxes interact with the physical climate and physiological functioning of plants and ecosystems. In the next section we identify numerous ways to obtain this information and illustrate how a network of long flux measurement sites can provide particularly useful information to study these complex problems.

\section{How to study biosphere $\mathrm{CO}_{2}$ exchange?}

Study of the earth's biogeochemistry and hydrology involves quantifying the flows of matter in and out of the atmosphere. Numerous techniques exist for studying biosphere-atmosphere $\mathrm{CO}_{2}$ exchange, each with distinct advantages and disadvantages. At the continental and global scales, scientists assess carbon dioxide sources and sinks using atmospheric inversion models that ingest information on fields of $\mathrm{CO}_{2},{ }^{13} \mathrm{C}$, and $\mathrm{O}_{2}$ concentration and wind (Tans et al. 1990; Ciais et al. 1995; Denning et al. 1996; Fan et al. 1998). This approach is subject to errors due to the sparseness of the trace gas measurement network, their biased placement in the marine boundary layer, and the accuracy of the atmospheric transport models (Tans et al. 1990; Denning et al. 1996; Fan et al. 1998).

Instruments mounted on satellite platforms view the earth in total. Consequently, satellite-based instruments offer the potential to evaluate surface carbon fluxes on the basis of algorithms that can be driven by reflected and emitted radiation measurements (Running et al. 1999; Cramer et al. 1999). This approach, however, is inferential, so it is dependent on the accuracy of the model algorithms, the frequency of satellite images, and the spectral information contained in the images.

At the landscape to regional scale we can use instruments mounted on aircraft (Crawford et al. 1996; Desjardins et al. 1984, 1997) or boundary layer budget methods (Denmead et al. 1996; Levy et al. 1999; Yi et al. 2000) to assess carbon and water fluxes. Aircraft-based eddy covariance flux density measurements give good information on spatial patterns of carbon and water fluxes across transects to tens to hundreds of kilometers. However, they do not provide information that is continuous in time, nor do they provide insights on the physiological mechanisms that govern carbon and water fluxes. Boundary layer budget methods can be implemented using tall towers, tethered balloons, or small aircraft. This method provides information on spatially integrated fluxes of tens to hundreds of square kilometers, but it can be applied only during ideal meteorological conditions (Denmead et al. 1996). Routine application of this method is hampered by a lack of data on entrainment and horizontal advection.

One measure of carbon flux "ground truth" can be provided by biomass surveys (Kauppi et al. 1992; Gower et al. 1999). However, biomass surveys provide information on multiyear to decadal timescales, so they do not provide information on shorter-term physiological forcings and mechanisms. Furthermore, forest inventory studies are labor intensive and are inferential estimates of net carbon exchange. Such studies rarely measure growth of small trees and belowground allocation of carbon. Instead biomass surveys commonly assume that a certain portion of carbon is allocated below ground (Gower et al. 1999). Soil carbon surveys can be conducted too but, like biomass surveys, they require long intervals to resolve de- 
tectable differences in net carbon uptake or loss (Amundson et al. 1998).

The eddy covariance method, a micrometeorological technique, provides a direct measure of net carbon and water fluxes between vegetated canopies and the atmosphere (Baldocchi et al. 1988; Foken and Wichura 1996; Aubinet et al. 2000). With current technology, the eddy covariance method is able to measure mass and energy fluxes over short and long timescales (hour, days, seasons, and years) with minimal disturbance to the underlying vegetation. Another attribute of the eddy covariance method is its ability to sample a relatively large area of land. Typical footprints have longitudinal length scales of 100-2000 m (Schmid 1994). If deployed as a coordinated network of measurements sites, the eddy covariance method has the potential of quantifying how whole ecosystems respond to a spectrum of climate regimes, thereby expanding the spatial scope of this method.

The eddy covariance method is not without weaknesses. Its application is generally restricted to periods when atmospheric conditions are steady and to locations with relatively flat terrain and vegetation that extends horizontally about 100 times the sampling height. Consequently, the method is not suitable for measuring fluxes in rough mountainous terrain or near distinct landscape transitions such as lakes.

Nevertheless, the strengths of the eddy covariance method far outweigh its weaknesses, as it can provide information that can aid in inferential carbon fluxes being determined by the global inversion model community, remote sensing scientists, and forest ecologists. For example, data from an eddy covariance measurement site have the potential to complement the global flask sampling network in a very direct way. Historically, the global flask sampling network has been concentrated at marine locations (Tans et al. 1990). Recent studies using tall towers show that there are times during the day, when either local surface fluxes are small or convective mixing is vigorous, that $\mathrm{CO}_{2}$ concentrations measured in the atmospheric surface layers are very close to the mean boundary layer concentration (Bakwin et al. 1998; Potosnak et al. 1999). High-precision $\mathrm{CO}_{2}$ concentration measurements and surface carbon flux measurements, made at eddy covariance measurement sites, have the potential to expand the density of the existing flask network. Data from a network of eddy covariance measurement sites can also be used to improve and validate the algorithms being used by remote sensing scientists and ecosystem modelers. And finally, such data can aid forest ecologists in their interpretation of forest biomass inventories, by providing information on fluxes from carbon pools and how these fluxes vary on a seasonal and interannual basis.

\section{History: What has been done?}

Micrometeorologists have been measuring $\mathrm{CO}_{2}$ and water vapor exchange between vegetation and the atmosphere since the late 1950s and early 1960s. Yet, only recently have we had the technology available that enables us to make continuous flux measurements at numerous sites.

The earliest reported micrometeorological measurements of $\mathrm{CO}_{2}$ exchange were conducted by Inoue (1958), Lemon (1960), Monteith and Sziecz (1960), and Denmead (1969). These studies employed the flux-gradient method over agricultural crops during the growing season. By the late 1960s and early 1970s, a few scientists started applying the flux-gradient method over natural landscapes. Several flux-gradient studies of $\mathrm{CO}_{2}$ exchange were conducted over forests (Denmead 1969; Baumgartner 1969; Jarvis et al. 1976), and one team ventured to assess the annual carbon balance of a salt marsh (Houghton and Woodwell 1980).

As more data were collected it became evident that the flux-gradient method was suffering from major deficiencies, when applied over tall forests. One flaw arose from large-scale transport in the roughness sublayer, which caused local eddy exchange coefficients to be enhanced relative to estimations based on Monin-Obukhov scaling theory (Rapauch and Legg 1984; Kaimal and Finnigan 1994). The flux-gradient method also failed to provide reliable means of evaluating eddy exchange coefficients at night.

Routine application of the eddy covariance method was delayed until the 1980s, when technological advances in sonic anemometry, infrared spectrometry, and digital computers were made. Initial studies were conducted over crops (Anderson et al. 1984; Desjardins et al. 1984; Ohtaki 1984), forests (Verma et al. 1986), and native grasslands (Verma et al. 1989) for short intense periods during the peak of the growing season. By the late 1980s and early 1990s, the further technological developments, such as larger data storage capacity and linear and nondrifting instruments, enabled scientists to make defensible measurements of eddy fluxes for extended periods. Wofsy et al. (1993), at Harvard Forest, and Vermetten et al. (1994), in the Netherlands, were among the first investigators 
to measure carbon dioxide and water vapor fluxes continuously over a forest over the course of a year with the eddy covariance method. Spurred by these two pioneering studies, a handful of other towers were soon established and operating by 1993 in North America [Oak Ridge, Tennessee (Greco and Baldocchi 1996); Prince Albert, Saskatchewan, Canada (Black et al. 1996)] and Japan (Yamamoto et al. 1999), and in Europe by 1994 (Valentini et al. 1996). This era also heralded the start of longer, quasi-continuous multi-investigator experiments. Noted examples include the Boreal Ecosystem-Atmosphere Study (Sellers et al. 1997) and the Northern Hemisphere Climate-Processes Land-Surface Experiment (Halldin et al. 1999).

The next natural step in the evolutionary development of this field was to establish a global network of research sites. The concept of a global network of longterm flux measurement sites had a genesis as early as 1993, as noted in the science plan of the International Geosphere-Biosphere Program/Biospheric Aspects of the Hydrological Cycle (BAHC Core Project Office 1993). Formal discussion of the concept among the international science community occurred at the 1995 La Thuile workshop (Baldocchi et al. 1996). At this meeting, the flux measurement community discussed the possibilities, problems, and pitfalls associated with making long-term flux measurements (e.g., Goulden et al. 1996a,b; Moncreiff et al. 1996). After the La Thuile meeting there was acceleration in the establishment of flux tower sites and regional flux measurement networks. The Euroflux project started in 1996 (Aubinet et al. 2000; Valentini et al. 2000). The AmeriFlux project was conceived in 1997, subsuming the several ongoing tower studies and initiating many new studies. With the success of the European and American regional networks and anticipation of the Earth $\mathrm{Ob}$ servation Satellite (EOS/Terra), the National Aeronautics and Space Administration (NASA) decided, in 1998, to fund the global-scale FLUXNET project, as a means of validating EOS products.

\section{What is being done?}

The FLUXNET project serves as a mechanism for uniting the activities of several regional and continental networks into an integrated global network. At present over 140 flux tower sites are registered on the FLUXNET data archive. Research sites are operating across the globe (Fig. 1) in North, Central, and South America; Europe; Scandinavia; Siberia; Asia; and Africa. The regional networks include AmeriFlux [which includes Large-scale Biosphere-Atmosphere Experiment (LBA) sites in Brazil], CarboEuroflux (which has subsumed Euroflux and Medeflu), AsiaFlux, and OzFlux (Australia, New Zealand). There are also disparate sites in Botswana and South Africa.

The global nature of FLUXNET extends the diversity of biomes, climate regions, and methods that are associated with the regional networks. For example, sites in the original Euroflux network consisted of conifer and deciduous forests and Mediterranean shrubland. The European networks also used a standard methodology, based on closed-path infrared spectrometers (Aubinet et al. 2000; Valentini et al. 2000). By contrast, the American network, AmeriFlux, has

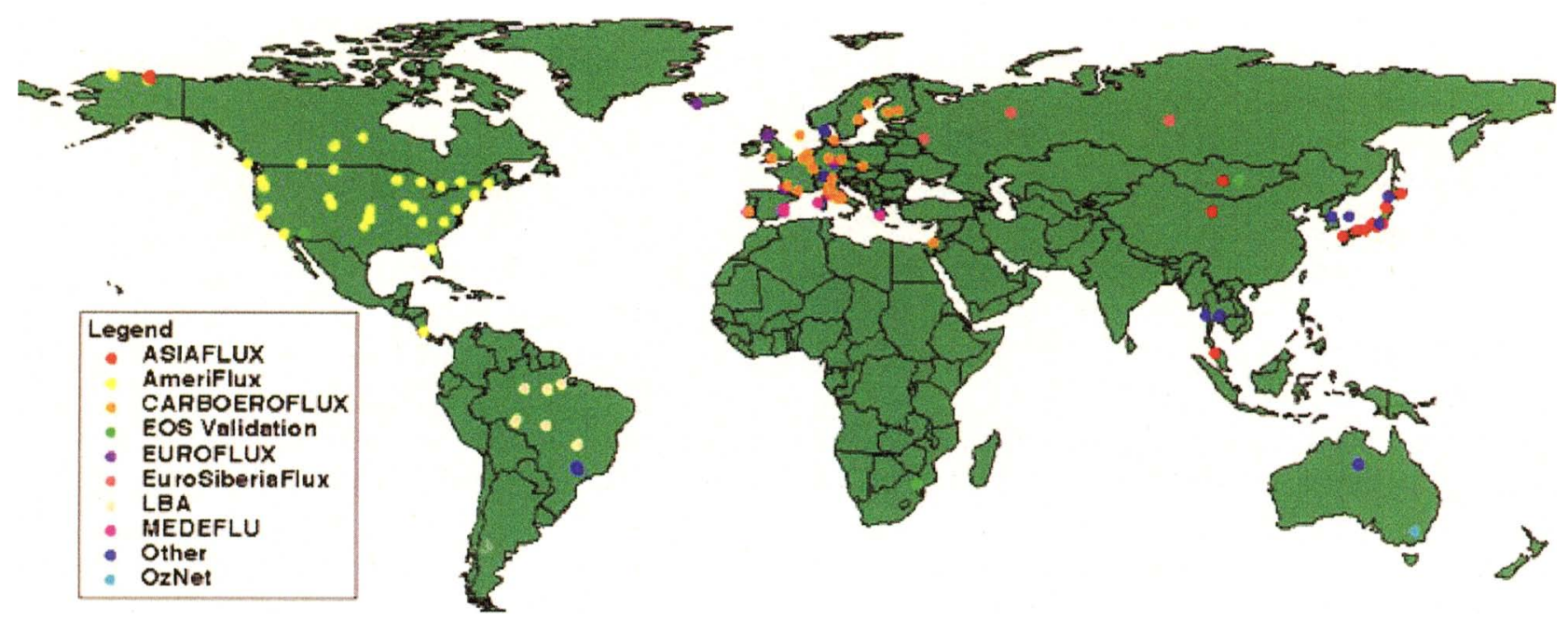

FIG. 1. Global map of FLUXNET field sites. 
more diversity in terms of the number of biomes and climates studied and methods used. The American regional network includes sites in temperate conifer and deciduous forests, tundra, cropland, grassland, chaparral, boreal forests, and tropical forests. Regarding methodology, open- and closed-path infrared spectrometers are used to measure $\mathrm{CO}_{2}$ and water vapor fluctuations. Another unique dimension of AmeriFlux is its inclusion of a tall $(400 \mathrm{~m})$ tower (Bakwin et al. 1998; Yi et al. 2000) for study of $\mathrm{CO}_{2}$ flux and concentration profiles and boundary layer evolution.

The placement of field sites in FLUXNET has been ad hoc, due to limited funding and investigator capabilities, rather than following a predetermined geostatistical design. So with the current network configuration, we are not capable of measuring fluxes from every patch on earth, nor do we intend to. On the other hand, this coordinated network of sites is able to deduce certain information on spatial patterns of fluxes by placing research sites across a spectrum of climate and plant functional regions (Running et al. 1999). Spatially integrated fluxes of carbon and water can only be constructed by combining eddy flux measurements with ecosystem and biophysical models and satellite measurements to perform the spatial integration (Running et al. 1999).

The scientific goals of FLUXNET are to

1) quantify the spatial differences in carbon dioxide and water vapor exchange rates that may be experienced within and across natural ecosystems and climatic gradients;

2) quantify temporal dynamics and variability (seasonal, interannual) of carbon, water, and energy flux densities - such data allow us to examine the influences of phenology, droughts, heat spells, El Niño, length of growing season, and presence or absence of snow on canopy-scale fluxes; and

3) quantify the variations of carbon dioxide and water vapor fluxes due to changes in insolation, temperature, soil moisture, photosynthetic capacity, nutrition, canopy structure, and ecosystem functional type.

FLUXNET has two operational components, a project office and a data archive office. The project office houses the principal investigator and a postdoctoral scientist. Specific duties of the FLUXNET office include

1) communicating with participants to ensure the timely submission of data and documentation to the data archive,
2) constructing and analyzing integrated datasets for synthesis of field data and for the development and testing of soil-atmosphere-vegetation-transfer models,

3) organizing workshops for data synthesis and model testing activities,

4) preparing peer-reviewed research papers and reports on FLUXNET activities and analyses,

5) funding the execution and analysis of site intercomparison studies, and

6) providing scientific guidance to the FLUXNET Data and Information System (DIS).

The data archive office is responsible for

1) compiling and documenting data in consistent formats,

2) developing data guidelines and coordinating development of the FLUXNET DIS,

3) scrutinizing datasets with standard quality control and assurance procedures,

4) maintaining the FLUXNET Web page for communications and data exchange (http://wwweosdis.ornl.gov/FLUXNET/), and

5) transferring FLUXNET data and metadata to a long-term archive, currently designated as the Oak Ridge National Laboratory Distributed Active Archive Center.

Back up of data and long-term accessibility of the data, provided by FLUXNET DIS, ensures the protection and extended use of the data by project scientists, as well as students and citizens, well into the future.

FLUXNET does not fund tower sites directly, but depends upon institutional support associated with the funding of the AmeriFlux, CarboEuroflux, AsiaFlux, and OzFlux networks (see acknowledgments).

\section{Methodology}

The eddy covariance method is used to assess trace gas fluxes between the biosphere and atmosphere at each site within the FLUXNET community (Aubinet et al. 2000; Valentini et al. 2000). Vertical flux densities of $\mathrm{CO}_{2}\left(F_{c}\right)$ and latent $(\lambda E)$ and sensible heat $(H)$ between vegetation and the atmosphere are proportional to the mean covariance between vertical velocity $\left(w^{\prime}\right)$ and the respective scalar $\left(c^{\prime}\right)$ fluctuations (e.g., $\mathrm{CO}_{2}$, water vapor, and temperature). Positive flux densities represent mass and energy transfer into the atmosphere and away from the surface, and negative values denote the reverse; ecologists use an opposite 
sign convention where the uptake of carbon by the biosphere is positive. Turbulent fluctuations were computed as the difference between instantaneous and mean scalar quantities.

Our community is interested in assessing the net uptake of carbon dioxide by the biosphere, not the flux across some arbitrary horizontal plane. When the thermal stratification of the atmosphere is stable or turbulent mixing is weak, material diffusing from leaves and the soil may not reach the reference height $z_{r}$ in a time that is short compared to the averaging time $T$, thereby violating the assumption of steady-state conditions and a constant flux layer. Under such conditions the storage term becomes nonzero, so it must be added to the eddy covariance measurement to represent the balance of material flowing into and out of the soil and vegetation (Wofsy et al. 1993; Moncrieff et al. 1996). With respect to $\mathrm{CO}_{2}$, the storage term is small over short crops and is an important quantity over taller forests. The storage term value is greatest around sunrise and sunset, when there is a transition between respiration and photosynthesis and between the stable nocturnal boundary layer and daytime convective turbulence (Aubinet et al. 2000; Yi et al. 2000). Summed over $24 \mathrm{~h}$, the storage term is nil (Baldocchi et al. 2000).

Horizontal advection is possible when vegetation is patchy or is on level terrain (Lee 1998; Finnigan 1999). At present, routine corrections for advection may require a three-dimensional array of towers (Finnigan 1999), rather than the application of a vertical velocity advection correction (see Lee 1998; Baldocchi et al. 2000).

\section{Instrumentation, data acquisition, and processing}

Typical instrumentation at FLUXNET field sites includes a three-dimensional sonic anemometer, to measure wind velocities and virtual temperature, and a fast responding sensor to measure $\mathrm{CO}_{2}$ and water vapor. Scalar concentration fluctuations are measured with open- and closed-path infrared gas analyzers. Standardized data processing routines are used to compute flux covariances (Foken and Wichura 1996; Moncrieff et al. 1996; Aubinet et al. 2000).

Application of the eddy covariance methods involves issues relating to site selection, instrument placement, sampling duration and frequency, calibration and postprocessing (Moore 1986; Baldocchi et al. 1988; Foken and Wichura 1996; Moncrieff et al. 1996;
Aubinet et al. 2000). Ideally the field site should be flat, with an extensive fetch of uniform vegetation. In practice many of the FLUXNET sites are on undulating or gently sloping terrain, as this is where native vegetation exists. Sites on extreme terrain, which may force flow separation and advection, are excluded. The degree of uniformity of the underlying vegetation varies across the network, too. Some sites consist of monospecific vegetation, others contain a mixture of species and a third grouping possesses different plant functional types in different wind quadrants. All sites have sufficient fetch to generate an internal boundary layer where fluxes are constant with height (Kaimal and Finnigan 1994).

Agricultural scientists mount their sensors on small poles, while forest scientists use either walk-up scaffolding or low-profile radio towers. The height of the sensors depends on the height of the vegetation, the extent of fetch, the range of wind velocity, and the frequency response of the instruments. To minimize tower interference on scaffold towers, investigators place their instruments booms so that they point several meters upwind or at the top of the tower. Spatial separation between anemometry and gas analyzers depend on whether one uses a closed- or open-path gas sensor. With the closed-path systems, the intake is often near or within the volume of the sonic anemometers. A delay occurs as air flows through the tubing to the sensor, which is compensated for with software during postprocessing. Some investigators place their gas transducer on the tower in a constant environment box to minimize the lag time from the sample port and the sensor. Others draw air down long tubes to instruments housed in an air-conditioned hut below the tower. In either circumstance, flow rates are high $\left(6 \mathrm{~L} \mathrm{~min}^{-1}\right)$ to ensure turbulent flow and minimize the diffusive smearing of eddies (Aubinet et al. 2000). Open-path gas sensors are typically placed within $0.5 \mathrm{~m}$ of a sonic anemometer, a distance that minimizes flow distortion and lag effects (Baldocchi et al. 2000; Meyers 2001).

Sampling rates between 10 and $20 \mathrm{~Hz}$ ensure complete sampling of the high-frequency portion of the flux cospectrum (Anderson et al. 1984). The sampling duration must be long enough to capture lowfrequency contributions to flux covariances, but not too long to be affected by diurnal changes in temperature, humidity, and $\mathrm{CO}_{2}$. Adequate sampling duration and averaging period vary between 30 and $60 \mathrm{~min}$ (Aubinet et al. 2000). Coordinate rotation calculations of the orthogonal wind vectors $(w, u, v)$ are performed 
to correct for instrument misalignment and nonlevel terrain. The vertical velocity, $w$, is rotated to zero, allowing flux covariances to be computed orthogonal to the mean streamlines.

Calibration frequencies of gas instruments vary from team to team. With closed-path sensors, investigators are able to calibrate frequently and automatically, such as hourly or once a day. Teams with open-path sensors calibrate less frequently, for example, every few weeks. However, a body of accumulating data indicates that calibrating coefficients of contemporary instruments remain steady within that duration ( $\pm 5 \%$; Meyers 2001). Scientists using openpath sensors also compare their instrument responses to an independent measure of $\mathrm{CO}_{2}$ concentration and humidity. Members of this network do not use a uniform standard for calibration $\mathrm{CO}_{2}$, yet. But many of us use $\mathrm{CO}_{2}$ gas standards that are traceable to the standards at the Climate Monitoring and Diagnostics Laboratory of the National Oceanic and Atmospheric Administration, the standards of the global flask network.

To ensure network intercomparability, the AmeriFlux project circulates a set of reference sensors to members in the network, and the FLUXNET project sponsors the circulation of this set of instruments to sites in Europe, Asia, and Australia. Figure 2 shows a typical comparison between the roving set of reference instrumentation and data from one research group. Carbon dioxide flux densities measured by the two systems agree within $5 \%$ of one another on an hourby-hour basis. A similar level of agreement has been

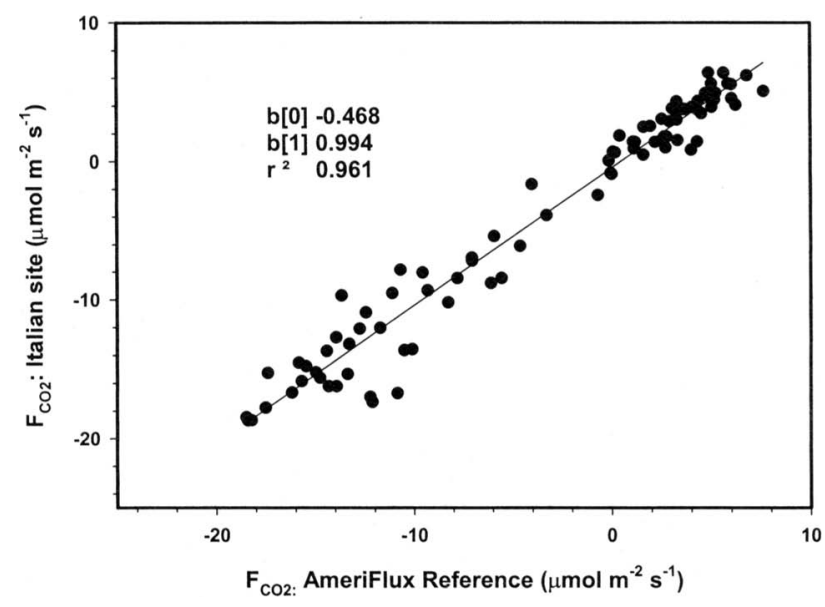

FIG. 2. A comparison of $\mathrm{CO}_{2}$ flux densities between the FLUXNET reference set of instruments and instruments at the Italian CarboEuroflux site. Here $b(0)$ is the zero intercept and $b(1)$ is the slope of the regressive curve, and $r^{2}$ is the coefficient of determination. found by comparing open- and closed-path $\mathrm{CO}_{2}$ sensors. Side-by-side comparisons between open- and closed-path water vapor sensors, on the other hand, are not as good. The absorption and desportion of water vapor on tubing walls can cause water uptake to be underestimated by $20 \%$.

\section{a. Gap filling}

Most clients of eddy flux data, for example modelers, require uninterrupted time series. It is the intent of the micrometeorological community to collect eddy covariance data 24 hours a day and 365 days a year. However, missing data in the archived records is a common feature. Gaps in the data record are attributed to system or sensor breakdown, periods when instruments are off-scale, when the wind is blowing through a tower, when spikes occur in the raw data, when the vertical angle of attack by the wind vector is too severe, and when data are missing because of calibration and maintenance. Other sources of missing data arise from farming operations and other management activities (e.g., prescribed burn of grasslands). Rejection criteria applied to the data vary among the flux tower groups. Data might be rejected, when stationarity tests or integral turbulence characteristics fail (Kaimal and Finnigan 1994; Foken and Wichura 1996), when precipitation limits the performance of open-path sensors, during sensor calibration, or when spikes occur in instrument readings. Other criteria used to reject data include applications of biological or physical constraints (lack of energy balance closure; Aubinet et al. 2000) and a meandering flux-footprint source area (e.g., Schmid 1994). If the wind is coming from a nonpreferred direction as may occur over mixed stands, a certain portion of the data will need to be screened. In addition, rejection probability for some sites is higher during nighttime because of calm wind conditions.

The average data coverage during a year is between $65 \%$ and $75 \%$ due to system failures or data rejection (Falge et al. 2001). Tests show that this observed level of data acceptance provides a statistically robust and oversampled estimate of the ensemble mean. So the filling of missing data does not provide a significant source of bias error.

\section{b. Accuracy assessment}

Errors associated with the application of the eddy covariance method can be random or biased (Moncrieff et al. 1996). Random errors arise from sensor noise and the random nature of atmospheric turbulence. Fully systematic bias errors arise from errors due to sensor 
drift, limited spectral response of instruments, limited sampling duration and frequency, and calibration errors. Selectively systematic bias errors arise from misapplication of the eddy covariance method, as when advection or storage occurs. Formal discussions on errors associated with long-term flux measurements were reported in previous papers by our colleagues (e.g., Goulden et al. 1996a; Moncrieff et al. 1996; Aubinet et al. 2000). For clarification, we provide a summary of their findings. Moncrieff et al. (1996) demonstrate how random sampling errors diminish greatly as the number of samples increase. The overall random error using a dataset of 44 days is about $0.4 \mu \mathrm{mol} \mathrm{m} \mathrm{m}^{-2} \mathrm{~s}^{-1}$. This figure of merit is close to the "flux detection" level that many of us see with our field measurements. Accumulated over a year, this random error is $\pm 53 \mathrm{~g} \mathrm{C} \mathrm{m}^{-2} \mathrm{yr}^{-1}$, a value that agrees with a formal error analysis by Goulden et al. (1996a,b).

Fully systematic bias errors associated with imperfect sensor response, sensor orientation, and sampling frequency and duration are typically compensated by applying spectral transfer functions to the flux covariance calculations (Moore 1986; Massman 2000). Depending on instrument configuration, wind speed, and thermal stratification, corrections can range from a few to 50 percent.

Selectively systematic bias errors are more difficult to assess. A cohort of carbon flux researchers suspect that they may be underevaluating the nighttime measure of $\mathrm{CO}_{2}$ fluxes, despite attempts to measure the storage term (Black et al. 1996; Goulden et al. 1996a; Baldocchi et al. 2000; Aubinet et al. 2000). Potential explanations include insufficient turbulent mixing, incorrect measurement of the storage term of $\mathrm{CO}_{2}$ in the air space and soil, and the drainage of $\mathrm{CO}_{2}$ out of the canopy volume at night. At present, several teams of investigators are applying an empirical correction to compensate for the underestimation of nighttime carbon flux measurements. This correction is based on $\mathrm{CO}_{2}$ flux density measurements obtained during windy periods or by replacing data with a temperaturedependent respiration function (Black et al. 1996; Goulden et al. 1996a,b; Lindroth et al. 1998). Most researchers presume that data from windy periods represent conditions when the storage and drainage of $\mathrm{CO}_{2}$ is minimal (Aubinet et al. 2000).

When using FLUXNET data, the user should recognize that some sites are more suitable for constructing annual sums than others. Yet good science can be produced from the nonideal sites, too. They can provide information on physiological functioning, tem- poral dynamics, and response to the environment during the day. We also note that the factors that cause large bias errors associated with nocturnal $\mathrm{CO}_{2}$ fluxes may not cause significant errors to water vapor fluxes, since evaporative fluxes are near zero during the night. Consequently, studies comparing integrated annual measurements of evaporation with lysimeters and watersheds show good agreement (Barr et al. 2000; Wilson et al. 2000). On the other hand, tests of surface energy balance closure suggest that turbulent fluxes at some sites are systematically $10 \%$ to $30 \%$ too small to close the energy budget, raising the possibility that $\mathrm{CO}_{2}$ fluxes are similarly underestimated (Aubinet et al. 2000). The solution to this problem remains unresolved at the time of this writing.

\section{Recent findings}

As we write this report, 69 site-years of carbon dioxide and water vapor flux data have been published in the literature. Table 1 presents a survey of the annual sums of net carbon dioxide exchange. Most sites are net sinks of $\mathrm{CO}_{2}$ on an annual basis. Magnitudes of net carbon uptake by whole ecosystems range from near zero to up to over $700 \mathrm{~g} \mathrm{C} \mathrm{m}^{-2} \mathrm{yr}^{-1}$. Largest values of carbon uptake are associated with temperate forests (conifer and deciduous) growing near the southern edge of that climate range. The substantial rate of net carbon uptake by tropical and temperate forests sites, under study, is an indicator that these sites have experienced substantial amounts of disturbances in the relatively near past (50-100 yr) and have not reached long-term steady state.

On close inspection of Table 1, we note that several sites are sources of $\mathrm{CO}_{2}$. Sites losing carbon dioxide include boreal forests and tundra, which are experiencing disturbance of long-term carbon storage pools (Goulden et al. 1998; Lindroth et al. 1998; Oechel et al. 2000), and grasslands, which were burnt (Suyker and Verma 2000) or were suffering from drought (Meyers 2001). The maximum carbon lost by these sites on an annual basis does not exceed $100 \mathrm{~g} \mathrm{C} \mathrm{m}^{-2}$.

With the plethora of long-term carbon flux data available, we can quantify seasonal patterns of carbon fluxes across a variety of climates, biomes, and plant functional groups. Figure 3 shows the annual pattern of weekly $\mathrm{CO}_{2}$ exchange for several temperate broadleaved deciduous forests. Broadleaved forests lose carbon during the winter, when they are leafless and 
TABLE 1. List of published yearlong studies of net biosphere-atmosphere $\mathrm{CO}_{2}$ exchange, $N_{\mathrm{e}}$. Negative signs represent a loss of carbon from the atmosphere and a net gain by the ecosystem.

\begin{tabular}{|c|c|c|c|c|c|}
\hline Site & Vegetation & 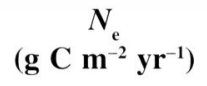 & $\begin{array}{c}\text { Observation } \\
\text { year }\end{array}$ & $\begin{array}{c}\text { Principal } \\
\text { investigator }\end{array}$ & Citation \\
\hline \multicolumn{6}{|c|}{ a. Temperate broadleaved deciduous forests } \\
\hline Italy & Beech, Fagus & -470 & 1994 & R. Valentini & Valentini et al. (1996) \\
\hline France & Beech, Fagus & $\begin{array}{l}-218 \\
-257\end{array}$ & $\begin{array}{l}1996 \\
1997\end{array}$ & A. Granier & Granier et al. (2000) \\
\hline Denmark & Beech, Fagus & $\begin{array}{l}-169 \\
-124\end{array}$ & $\begin{array}{l}1997 \\
1998\end{array}$ & N. O. Jensen & Pilegaard et al. (2001) \\
\hline Iceland & Poplar & -100 & 1997 & H. Thoreirsson & Valentini et al. (2000) \\
\hline $\begin{array}{c}\text { Saskatchwan, } \\
\text { Canada }\end{array}$ & Aspen & $\begin{array}{r}-160 \\
-144 \\
-80 \\
-116 \\
-290\end{array}$ & $\begin{array}{l}1994 \\
1994 \\
1996 \\
1997 \\
1998\end{array}$ & T. A. Black & Black et al. (1996) \\
\hline Oak Ridge, TN & $\begin{array}{c}\text { Acer, Quercus } \\
\text { Maple, oak }\end{array}$ & $\begin{array}{l}-525 \\
-610 \\
-597 \\
-652 \\
-656 \\
-739\end{array}$ & $\begin{array}{l}1994 \\
1995 \\
1996 \\
1997 \\
1998 \\
1999\end{array}$ & D. Baldocchi & $\begin{array}{c}\text { Greco and } \\
\text { Baldocchi (1996); } \\
\text { Wilson and } \\
\text { Baldocchi (2000) }\end{array}$ \\
\hline Petersham, MA & $\begin{array}{c}\text { Acer, Quercus } \\
\text { Maple, oak }\end{array}$ & $\begin{array}{l}-280 \\
-220 \\
-140 \\
-210 \\
-270\end{array}$ & $\begin{array}{l}1991 \\
1992 \\
1993 \\
1994 \\
1995\end{array}$ & S. Wofsy & $\begin{array}{l}\text { Wofsy et al. (1993) } \\
\text { Goulden et al. } \\
(1996 a, b)\end{array}$ \\
\hline Borden, ON, Canada & Maple, Acer & $\begin{array}{r}-80 \\
-270 \\
-200\end{array}$ & $\begin{array}{l}1996 \\
1997 \\
1998\end{array}$ & X. Lee/J. Fuentes & Lee et al. (1999) \\
\hline Indiana & Deciduous forest & -240 & 1998 & H. P. Schmid & Schmid et al. (2000) \\
\hline Takayama, Japan & Broadleaf deciduous & $\begin{array}{r}-120 \\
-70 \\
-140 \\
-150 \\
-140\end{array}$ & $\begin{array}{l}1994 \\
1995 \\
1996 \\
1997 \\
1998\end{array}$ & & $\begin{array}{l}\text { Yamomoto et al. } \\
\text { (1999) }\end{array}$ \\
\hline \multicolumn{6}{|c|}{ b. Mixed deciduous and evergreen forests, temperate and Mediterranean } \\
\hline Belgium & Conifer and broadleaf & -430 & 1997 & M. Aubinet & Valentini et al. (2000) \\
\hline Belgium & Conifer and broadleaf & -157 & 1997 & R. Ceulemans & Valentini et al. (2000) \\
\hline \multicolumn{6}{|l|}{ c. Tropical forests } \\
\hline Amazon & Tropical forest & -102 & 1995 & J. Grace & Malhi et al. (1998) \\
\hline \multicolumn{6}{|c|}{ d. Needleleaf, evergreen, conifer forests } \\
\hline Sweden & $\begin{array}{c}\text { Pinus sylvestris } \\
\text { Picea abies }\end{array}$ & $\begin{array}{r}90 \\
-5 \\
80 \\
-190\end{array}$ & $\begin{array}{l}1995 \\
1996 \\
1997 \\
1997\end{array}$ & A. Lindroth & Lindroth et al. (1998) \\
\hline Italy & Picea abies & -450 & 1998 & R. Valentini & Valentini et al. (2000) \\
\hline
\end{tabular}


Table 1. Continued.

\begin{tabular}{|c|c|c|c|c|c|}
\hline Site & Vegetation & $\begin{array}{c}N_{\mathrm{e}} \\
\left(\mathrm{g} \mathrm{C} \mathrm{m}^{-2} \mathrm{yr}^{-1}\right)\end{array}$ & $\begin{array}{c}\text { Observation } \\
\text { year }\end{array}$ & $\begin{array}{c}\text { Principal } \\
\text { investigator }\end{array}$ & Citation \\
\hline \multicolumn{6}{|c|}{ d. Needleleaf, evergreen, conifer forests } \\
\hline France & Pinus pinaster & -430 & 1997 & P. Berbigier & Berbigier et al. (2001) \\
\hline Germany & Picea abies & -77 & 1997 & & Valentini et al. (2000) \\
\hline Germany & Picea abies & $\begin{array}{r}-330 \\
-480 \\
-45\end{array}$ & $\begin{array}{l}1996 \\
1997 \\
1998\end{array}$ & Ch. Bernhofer & Valentini et al. (2000) \\
\hline Germany & Conifer & $\begin{array}{l}-310 \\
-490\end{array}$ & $\begin{array}{l}1996 \\
1997\end{array}$ & A. Ibrom & Valentini et al. (2000) \\
\hline Germany & Picea abies & -77 & 1997 & E.-D. Schulze & Valentini et al. (2000) \\
\hline Netherlands & Pinus sylvestris & -210 & 1997 & H. Dolman & Valentini et al. (2000) \\
\hline United Kingdom & Picea sitchensis & $\begin{array}{l}-670 \\
-570\end{array}$ & $\begin{array}{l}1997 \\
1998\end{array}$ & J. Moncrieff & $\begin{array}{l}\text { Valentini et al. (2000) } \\
\text { Valentini et al. (2000) }\end{array}$ \\
\hline Finland & Pinus sylvestris & $\begin{array}{l}-230 \\
-260 \\
-190\end{array}$ & $\begin{array}{l}1997 \\
1998 \\
1999\end{array}$ & T. Vesala & $\begin{array}{l}\text { Valentini et al. (2000) } \\
\text { Markkanen et al. } \\
(2001)\end{array}$ \\
\hline Howland, ME & Conifer & -210 & 1996 & D. Hollinger & Hollinger et al. (1999) \\
\hline Florida & Slash pine & $\begin{array}{l}-740 \\
-610\end{array}$ & $\begin{array}{l}1996 \\
1997\end{array}$ & H. Gholz & Clark et al. (1999) \\
\hline Florida & Cypress & $\begin{array}{l}-84 \\
-37\end{array}$ & $\begin{array}{l}1996 \\
1997\end{array}$ & H. Gholz & Clarke et al. (1999) \\
\hline Manitoba, Canada & Picea mariana & $\begin{array}{r}70 \\
20 \\
-10\end{array}$ & $\begin{array}{l}1995 \\
1996 \\
1997\end{array}$ & & Goulden et al. (1998) \\
\hline Metolius, OR & Pinus ponderosa & $\begin{array}{l}-320 \\
-270\end{array}$ & $\begin{array}{l}1996 \\
1997\end{array}$ & B. Law & Anthoni et al. (1999) \\
\hline Wind River, WA & Pseudotsuga menzieii & $\begin{array}{r}-167 \\
\text { to }-220\end{array}$ & 1998 & K. T. Paw U & $\begin{array}{l}\text { Paw U et al. (2000, } \\
\text { unpublished manuscript) }\end{array}$ \\
\hline $\begin{array}{l}\text { Prince Albert, } \\
\text { SK, Canada }\end{array}$ & Picea mariana & -68 & 1995 & P. Jarvis & Malhi et al. (1999) \\
\hline \multicolumn{6}{|c|}{ e. Broadleaved evergreen, Mediterranean forests } \\
\hline Italy & Quercus ilex & -660 & 1997 & R. Valentini & $\begin{array}{l}\text { Valentini et al. } \\
\qquad(2000)\end{array}$ \\
\hline \multicolumn{6}{|l|}{ f. Grassland } \\
\hline Ponca, OK & Tall-grass prairie & 0 & 1997 & S. B. Verma & $\begin{array}{l}\text { Suyker and Verma } \\
\qquad(2001)\end{array}$ \\
\hline Little Washita, OK & Grazed grassland & 41 & 1997 & & Meyers (2001) \\
\hline \multicolumn{6}{|l|}{ g. Tundra } \\
\hline Alaska & Tundra & 40 & & W. Oechel & Oechel et al. (2000) \\
\hline
\end{tabular}


dormant, and gain carbon during the summer growing season. What differs most among broadleaved forest sites is the timing of the transition between gaining and losing carbon. The site in the southeastern United States (Tennessee) is the first to experience spring growth and photosynthesis, followed by the site in Denmark and one in the northeast United States (Massachusetts). The Harvard Forest in Massachusetts is on the eastern side of the North American continent. It experiences a later spring than the more northerly Danish site because the climate of Denmark is moderated by the Gulf Stream. During the peak of the growing season, these three sites, separated by several thousand kilometers, experience similar daily sums of carbon uptake (around weeks 23-24). And the two North American sites, separated by over $1000 \mathrm{~km}$, experience similar weekly sums of net $\mathrm{CO}_{2}$ exchange from about week 23 to 35 . In the autumn, the Danish site is the first to drop leaves and respire, and the most southern site is last. Another feature to be gathered from this figure is how ideal and nonideal sites affect the measurement of respiration. During the winter the Tennessee site experiences extremely low rates of respiration. This site is situated on rolling terrain and near several power plants. Cold air drainage causes $\mathrm{CO}_{2}$ to drain out from under the flux tower, and plume impaction causes downward carbon fluxes that counter the upward respiratory flux.

Based on data in Fig. 3, one may suspect that phenological timing of spring and autumn would be a major factor causing site variability among net carbon exchange of temperate deciduous forests. We quantify this effect in Fig. 4 by plotting annual net eco-

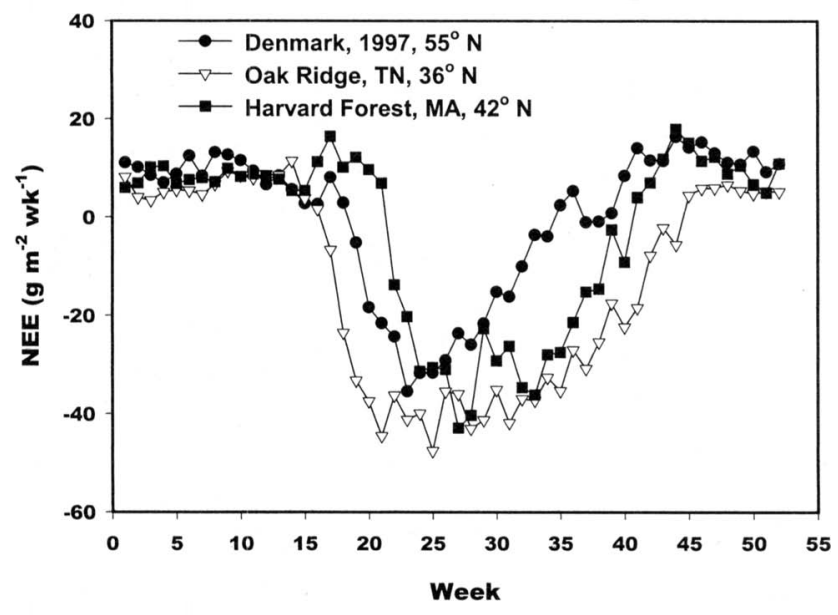

FIG. 3. Annual course of weekly net ecosystem $\mathrm{CO}_{2}$ exchange (NEE) for three temperate deciduous forests, located in Oak Ridge, Tennessee; Petersham, Massachusetts; and Denmark. system $\mathrm{CO}_{2}$ exchange versus length of growing season in days; for convenience, we define the growing season as the period over which mean daily $\mathrm{CO}_{2}$ exchange is negative, due to net uptake by the biosphere. We observe that net ecosystem $\mathrm{CO}_{2}$ exchange increases $5.7 \mathrm{~g} \mathrm{C} \mathrm{m}^{-2}$ for each day that the length of the growing season increases. The predictive power of this result is very robust, as variations in the length of the growing season account for $83 \%$ of the variance of $\mathrm{CO}_{2}$ exchange that is observed. The coherent response of net ecosystem $\mathrm{CO}_{2}$ exchange of the deciduous forest biome reflects their broadly similar growing season climate, age, and disturbance history. It also gives us confidence in the accuracy of independent research sites across the network. On the basis of this figure, one may conclude that site-to-site measurement errors and biases may be relatively small compared to variance caused by ecological and meteorological factors.

In Fig. 4, we also added a data point from a tropical forest, which experiences a year-round growing season. On the basis of data from the Tropics we expect the regression curve to reach an asymptote as the growing extends beyond 220 days. Consequently, one

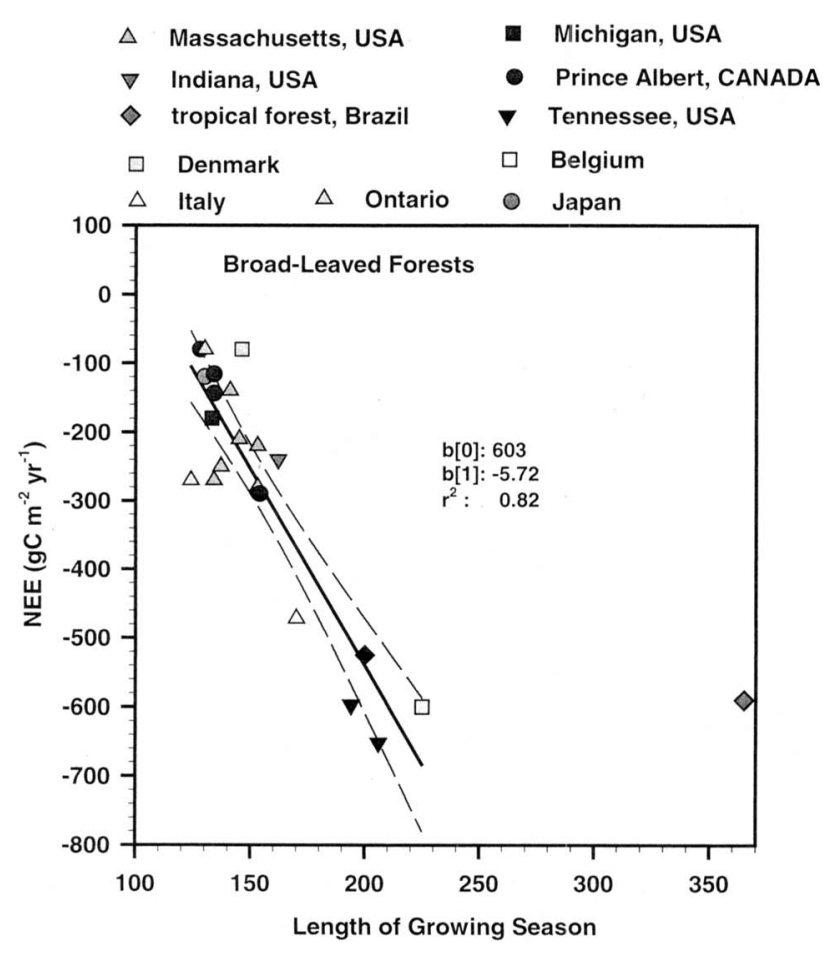

Fig. 4. Annual net ecosystem $\mathrm{CO}_{2}$ exchange: Impact of length of growing season (in days) on temperate broadleaved forests and one tropical forest (Brazil). Here, $b_{0}$ is the zero intercept and $b_{1}$ is the slope of the regression curve, and $r^{2}$ is the coefficient of determination. Dashed lines are the standard error of the regression at the $95 \%$ level. 


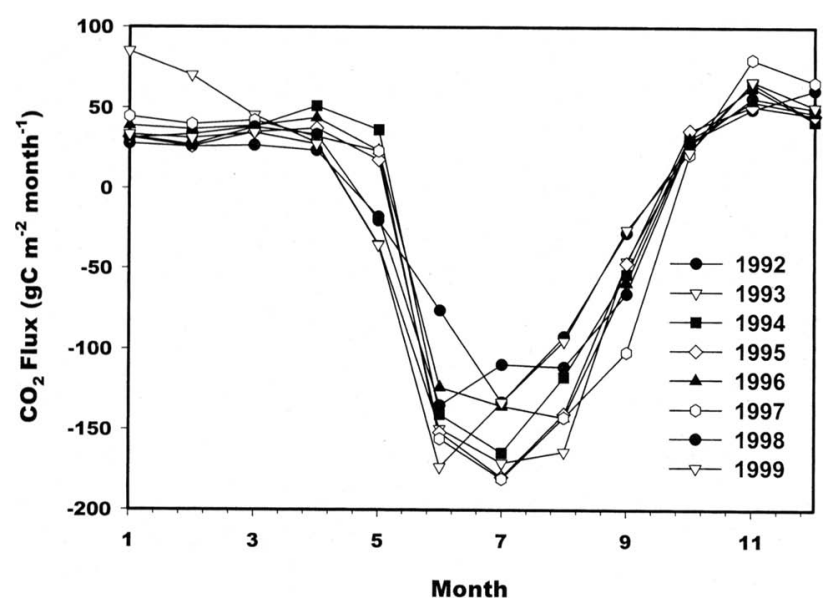

FIG. 5. Year-to-year variation in the annual cycle of monthly $\mathrm{CO}_{2}$ exchange at Harvard Forest, a broadleaved deciduous forest.

should not extrapolate the regression line out to 365 days. Nor do we advocate using this plot for estimating year-to-year variability in net ecosystem $\mathrm{CO}_{2}$ exchange at a site. To illustrate this point we show an example of year-to-year variation of the annual cycle of $\mathrm{CO}_{2}$ exchange at Harvard Forest (Fig. 5), the site with the world's longest measurement record. Other factors, such as the presence or absence of snow cover, degree of cloudiness (Goulden et al. 1996b; Lee et al. 1999), and drought (Wilson and Baldocchi 2000) impose variance on the annual carbon budget, too.

The seasonal trend of $\mathrm{CO}_{2}$ exchange experienced by conifer forests is affected by latitudinal differences, which shorten or lengthen the growing season, and by continental position, which forces conifer ecosystems to experience oceanic, Mediterranean, or continental climates. To illustrate these points we present data on seasonal patterns of net $\mathrm{CO}_{2}$ exchange from three contrasting conifer forest systems (Fig. 6). The North Carolina site is at a temperate and humid locale in the southeastern United States. There, the canopy is able to take up carbon all year. The Oregon site experiences cool, wet winters and dry, warm summers. It assimilates carbon during the late winter, spring, and autumn, but experiences large reductions in carbon dioxide uptake during the dry summer growing season (there are instances when it loses carbon, too). The Finnish site is in the boreal zone. The trees are dormant during the cold winter, but the forest stand loses carbon due to soil and microbial respiration under the snow pack. In the spring, the onset of photosynthesis is much delayed compared to the more southerly temperate sites, and its conclusion is sooner in the autumn.
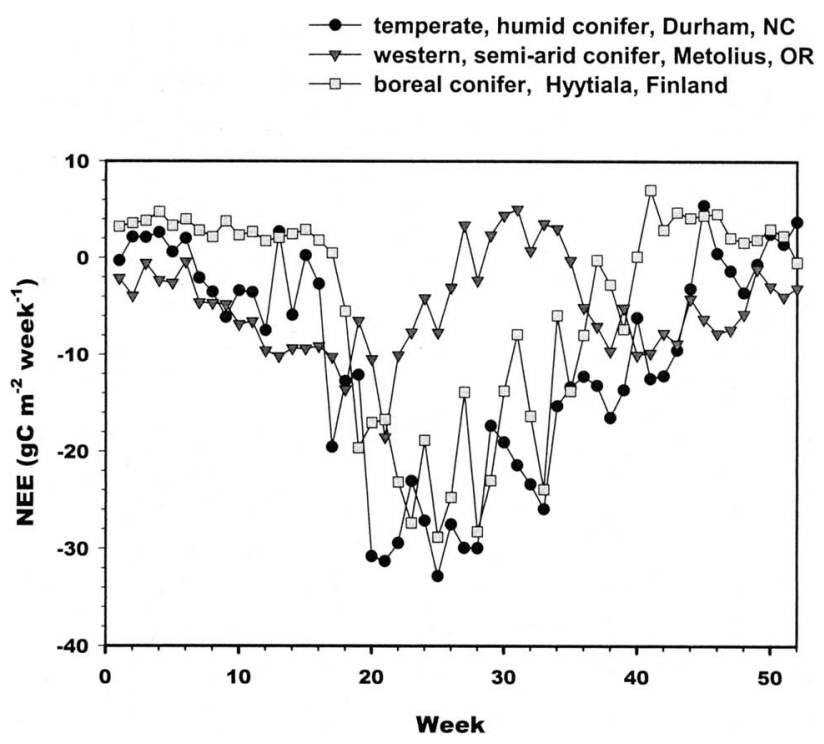

FIG. 6. Seasonal course of net weekly $\mathrm{CO}_{2}$ exchange over contrasting conifer forests during 1997.

With longer datasets, alternative analytical methods can be used to interpret them. Application of Fourier transforms to yearlong and multiyear flux measurement records provides a means of quantifying the timescales of flux variance (Baldocchi et al. 2001). The dominant time periods over which carbon dioxide fluxes vary can be days, weeks, seasons, and years. Figure 7 shows the power spectra of $\mathrm{CO}_{2}$ fluxes

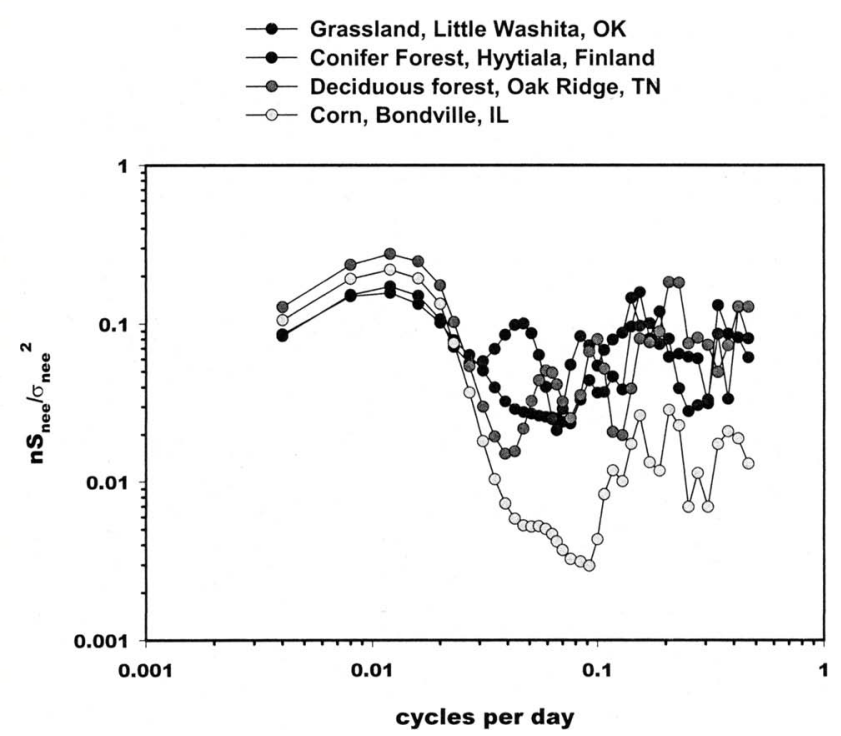

FIG. 7. Power spectrum of $\mathrm{CO}_{2}$ flux over the course of a year at sites of contrasting climate, functionality, and structure. Power spectra for the other sites were derived from time series of $1 \mathrm{yr}$ in duration. The power spectra on the $y$ axis are multiplied by natural frequency $(n)$ and are normalized by variance. 
over a variety of field sites on a daily timescale. These variations in $\mathrm{CO}_{2}$ and water vapor exchange are forced by daily rhythms in solar radiation, air and soil temperature, humidity, $\mathrm{CO}_{2}$, stomatal aperture, photosynthesis, and respiration. On a weekly timescale, fluctuations in $\mathrm{CO}_{2}$ and water vapor exchange are induced at midlatitude sites from synoptic weather changes that are associated with the passage of high and low pressure systems and fronts. Weather events cause distinct periods of clear sky, overcast, and partly cloudy conditions, which alter the amount of available light to an ecosystem, how light is transmitted through a plant canopy, and the efficiency by which it is used to assimilate carbon ( $\mathrm{Gu}$ et al. 1999). The passing of weather fronts also changes air temperature, humidity deficits, and pressure. On seasonal timescales, changes in the sun's position alter the amount of sunlight received, the air, soil, and surface temperature of the ecosystem, and its water balance. Superimposed upon these meteorological factors is a variance caused by phenology and seasonal changes in photosynthetic capacity (Wilson et al. 2000). The timing and occurrence of leaf expansion, senescence, leaf fall, fine root growth and turnover, and seasonal changes in photosynthetic capacity and leaf area index are examples of phenological factors affecting low-frequency fluctuations in canopy $\mathrm{CO}_{2}$ exchange. Prolonged wet and dry spells are other factors that exert variance on the spectral record.

Canopy-scale quantum yield represents the initial slope of the relation between net ecosystem $\mathrm{CO}_{2}$ exchange and the photosynthetic photon flux density. Canopy-scale quantum yield is of particular interest, as it is a parameter used by many biogeochemical car-

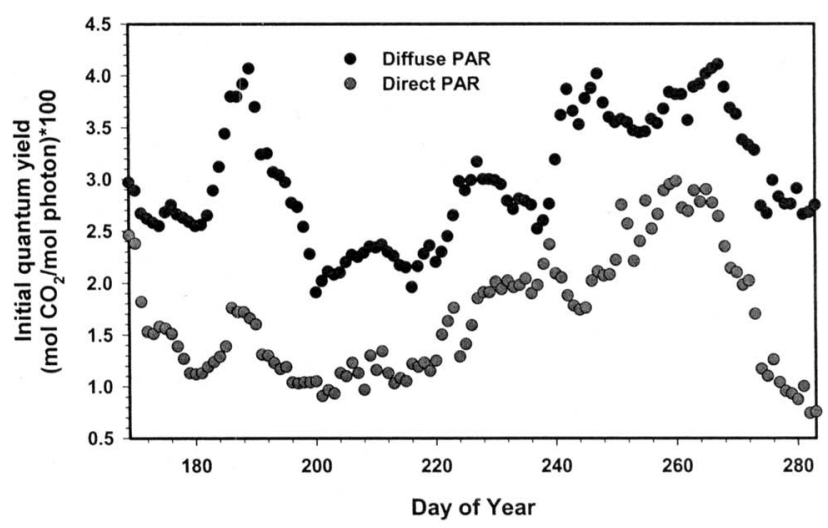

FIG. 8. Seasonal variation of initial quantum yield of a conifer (Scots) pine forest in Finland. Quantum yield is the initial slope of the response between canopy $\mathrm{CO}_{2}$ exchange and photosynthetic photon flux density. PAR is photosynthetically active radiation. bon cycling models to translate remotely sensed radiation measurements to an areawide estimate of carbon uptake (Ruimy et al. 1995; Cramer et al. 1999). Figure 8 shows that the canopy-scale quantum yield depends on the sky conditions, as well as temperature. The canopy-scale quantum yield is nearly double under cloudy skies, as compared to clear skies.

Combining data from the North American and European networks gives us a wider breadth of information on how $\mathrm{CO}_{2}$ flux densities respond to temperature. The temperate zone of Europe is displaced northward, as compared to North America, due to the presence of the Gulf Stream. Summer temperatures in Europe are on the order of $15^{\circ}-20^{\circ} \mathrm{C}$, while in North America summer temperatures are in the range of $20^{\circ}$ $30^{\circ} \mathrm{C}$. Figure 9 indicates that the temperature at which peak gross $\mathrm{CO}_{2}$ exchange occurs is several degrees lower for many European sites than for their North American counterparts. These data suggest that global carbon flux models will need to vary $\mathrm{CO}_{2}$ fluxtemperature response curves for North America and Europe, in support of findings by Niinemets et al. (1999).

With regard to meteorology, FLUXNET can provide new information on how the biosphere affects the partitioning of net radiation into sensible $(H)$ and latent heat $(\lambda E)$ exchange, as quantified by the Bowen ratio. Figure 10 shows the yearly course in Bowen ratio for several selected sites. During the winter, the Bowen ratio is variable, and in many instances large,

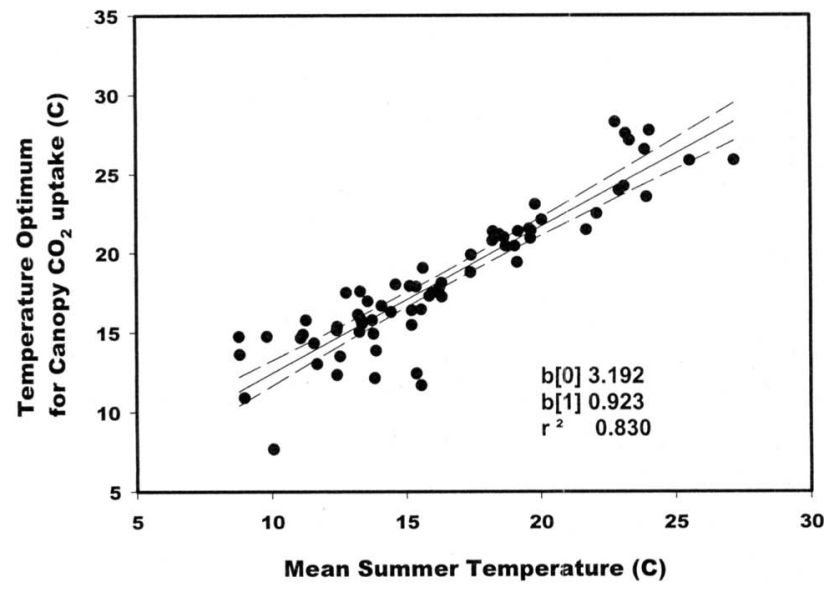

FIG. 9. The relation between the optimum temperature for canopy-scale gross primary productivity vs maximum mean monthly air temperature during the summer growing season. These data show how photosynthesis adapts to climate. Here $b(0)$ is the zero intercept and $b(1)$ is the slope of the regression curve, and $r^{2}$ is the coefficient of determination. Dashed lines are the standard error of the regression at the $95 \%$ level. 
with $H$ being up to 6 times greater than $\lambda E$. Occurrences of negative Bowen ratios are recorded as well and are attributed to radiative cooling and the presence of water on the surface. In both instances, stable thermal stratification is associated with the downward transfer of sensible heat. The timing of leaf-out in the temperate broadleaved forest and grassland biomes affects the Bowen ratio markedly. The presence of leaves causes Bowen ratios to drop in magnitude, compared to their leafless states, and range between 0 and 1 . The timing of leaf-out also has a distinct impact on the humidity and temperature of the planetary boundary layer (Schwartz 1996) and the seasonal pattern of its maximum height (Wilson and Baldocchi 2000; Yi et al. 2000).

There is a growing trend toward using coupled carbon-water flux models in global climate and fore-
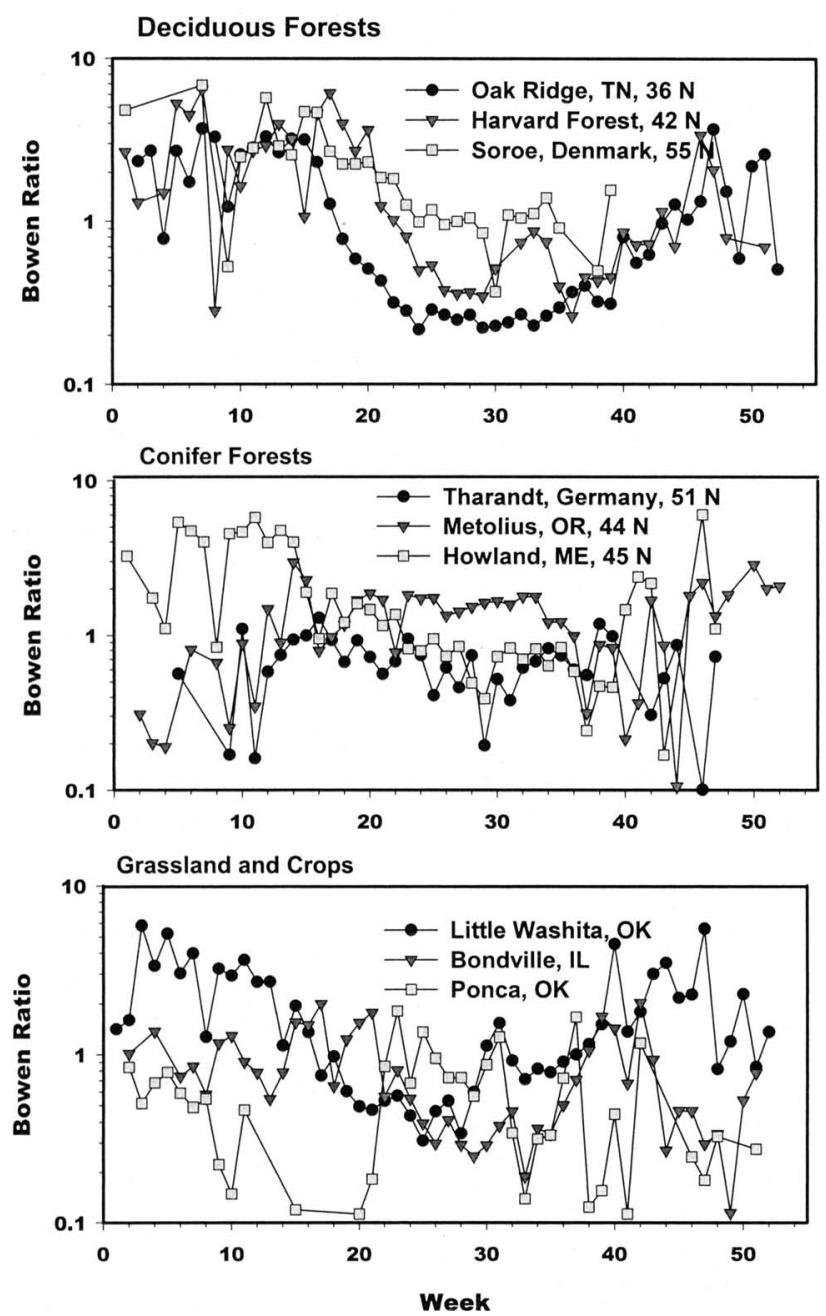

FIG. 10. Seasonality of Bowen ratio, the ratio between sensible and latent heat flux densities, at representative deciduous forests, conifer forests, and grassland and crop sites. casting models (Foley et al. 1998). The trend is warranted because information on photosynthesis constrains the information on stomatal conductance, a variable needed to compute sensible and latent heat exchange. Figure 11 shows how well carbon and water fluxes are coupled for two functional forest groups. Water use efficiency can be defined as the regression slope between NEE and LE in Fig. 11. We observe that broadleaved forests use water more efficiently than conifer forests, by a factor of almost 1.5. Furthermore, variations in latent heat flux explain more of the variance in $\mathrm{CO}_{2}$ exchange of broadleaved forests than it does for conifer forests; the coefficients of variation were 0.77 and 0.42 , respectively. Another conclusion that can be drawn from this information relates to carbon sequestration and carbon storage. Greater carbon uptake cannot be achieved without the availability and use of water. Ecosystems with high rates of carbon uptake use more water.

The Euroflux community published results showing that gross primary productivity is relatively constant (Valentini et al. 2000). Theoretical calculations also support the idea that gross primary productivity is relatively constant for the range site characteristics
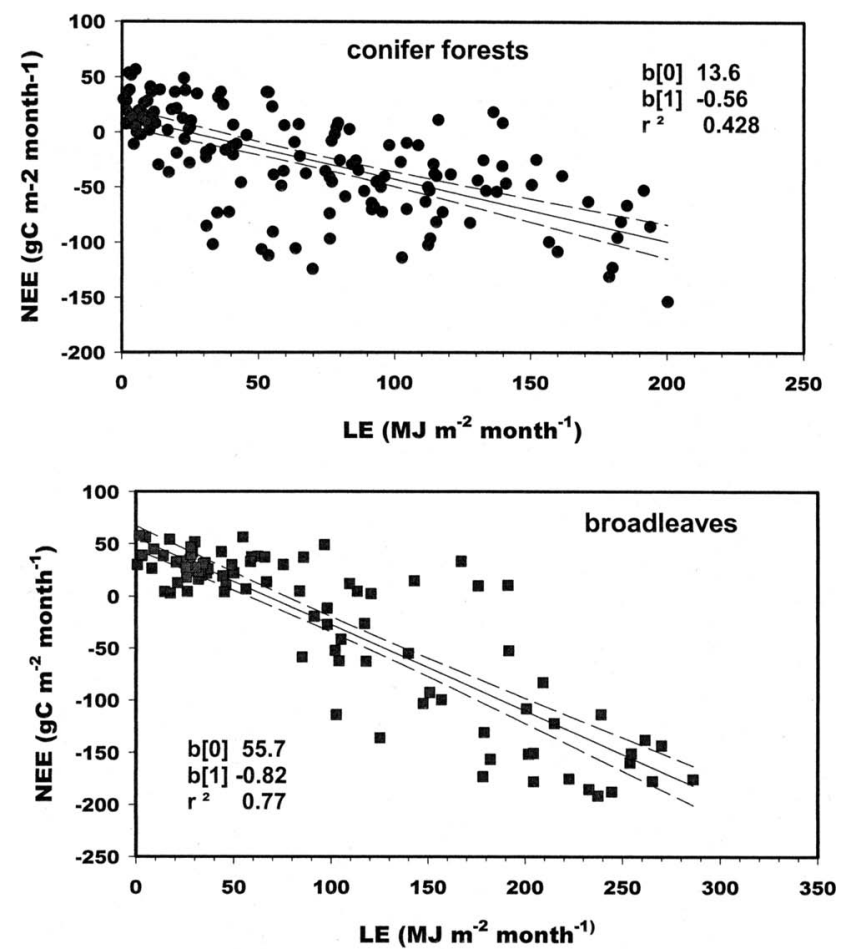

FIG. 11. The linkage between carbon (NEE) and water fluxes (LE) for conifer and temperate forests (broadleaves). Here $b_{0}$ is the zero intercept, $b_{1}$ is the slope of the regression curve, and $r^{2}$ is the coefficient of determination. 
studied by the Euroflux network. The Euroflux data, however, come from a relatively narrow range of plant architectural and functional types (closed conifer and deciduous forests) and climate conditions, so one can question how applicable the results may be across a wider range of conditions. Using a biophysical model (Baldocchi and Meyers 1998), we predict that gross primary productivity (GPP) of plants via photosynthesis is an asymptotic function of leaf area index, leaf nitrogen, and the fraction of photosynthetically active radiation that the canopy intercepts (Fig. 12).

There is a growing body of literature that is attempting to understand the impact of stand age on carbon and water fluxes (Amiro et al. 1999; Schulze et al. 1999; Law et al. 2001, manuscript submitted to Global Change Biol.; K. T. Paw U et al. 2001, manuscript submitted to Ecosystems). Productivity is assumed to diminish with age, and disturbances affect the relative ratio between canopy carbon uptake and soil respiration, and the ratio between canopy transpiration and soil evaporation. An attribute of a global network, such as FLUXNET, is the occurrence of sites with similar species and functionality but different ages. Based on the data surveyed in Table 1, part d, we can draw the conclusion that the net carbon exchange of old growth conifer forests is not carbon neutral (e.g., K. T. Paw U et al. 2001, manuscript submitted to Ecosystems). A direct comparison of flux densities of carbon dioxide and water vapor that were measured over an old age Ponderosa pine stand in

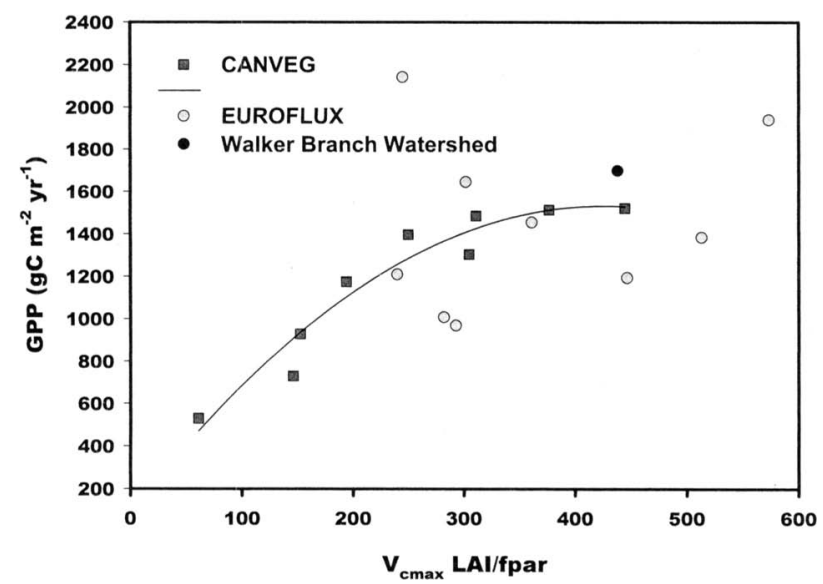

FIG. 12. The relation between gross primary productivity (GPP) and plant physiological capacity using field data and a biophysical model. The index of plant physiological capacity is a function of the maximum carboxylation velocity of photosynthesis $(V \mathrm{cmax})$, leaf area index (LAI), and the fraction of absorbed visible sunlight ( $f$ par). The Euroflux field data are reported in Valentini et al. (2000).
Oregon (Metolius) and a young stand in northern California (Blodgett) are shown in Fig. 13. Peak rates of evaporation are almost triple for the young stand, as compared to the old stand. Net daytime carbon assimilation fluxes of the young and old stands are out of phase during the summer growing season (seen at 18 months in Fig. 13). The old stand is most productive during the spring and autumn periods, while soil water deficits restrict summertime rates of $\mathrm{CO}_{2}$ uptake. The young stand experiences greatest rates of uptake during the summer, and peak rates of the young stand can exceed peak rates of the old stand in the summer by $14 \%\left(-140 \mathrm{~g} \mathrm{C} \mathrm{m}^{-2}\right.$ month $^{-1}$ near month 30 vs -120 near month 18). Simulation modeling, which includes the effects of tree age, suggested that the milder winters and ample annual rainfall in the young stand allow it to have a higher leaf area than the old forest, allowing more carbon uptake through the year (Law et al. 2001, manuscript submitted to Global Change Biol.). Site management also has a substantial impact on carbon and water fluxes at the

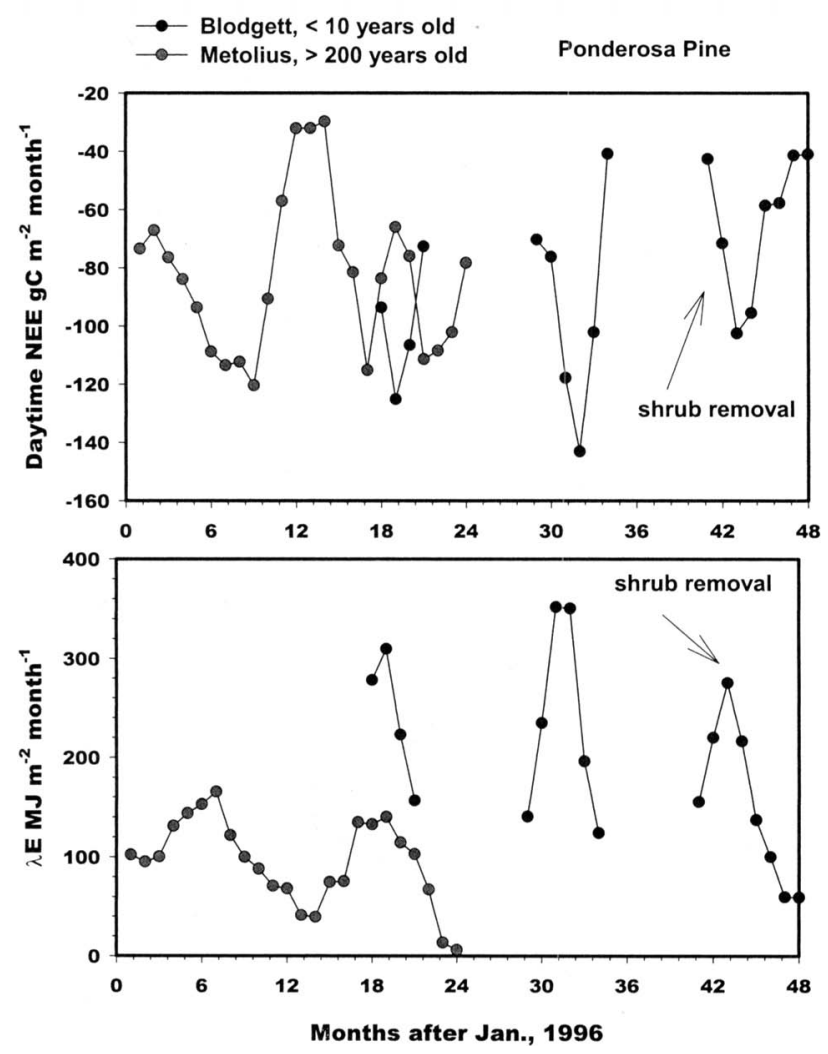

FIG. 13. The impact of stand age on daytime $\mathrm{CO}_{2}$ exchange (NEE) and latent heat exchange (LE). The data are from a young ( $<10 \mathrm{yr}$; black circles) and an old (> $200 \mathrm{yr}$; gray circles) ponderosa pine forest (see Law et al. 2001, manuscript submitted to Global Change Biol.; Goldstein et al. 2000). 
young site. The removal of understory shrubs in 1999 reduced both $\mathrm{CO}_{2}$ uptake and evaporation.

\section{Conclusions}

A global network of long-term measurement sites has been established and is producing new information on how $\mathrm{CO}_{2}$ and water vapor between the terrestrial biosphere and atmosphere vary across a broad spectrum of biomes, climates, and timescales. The science generated so far indicates that rates of net carbon uptake by tropical and temperate forests are substantial and exceed estimates previously generated with biospheric modeling systems. Gross primary productivity of forest ecosystems may not be constant, but may depend on plant architecture (e.g., on leaf area), foliage photosynthetic capacity, and the amount of sunlight absorbed.

Carbon net ecosystem exchange of broadleaved deciduous forests strongly depends on length of growing season, but is sensitive to perturbations such as droughts, clouds, winter snow cover, and early thawing, too. Concerning conifer forests, the conclusions are not as unifying. Seasonal and annual sums of net carbon exchange by boreal, semiarid, temperate, and humid conifers differ among one another and for different physiological reasons.

The response of canopy-scale $\mathrm{CO}_{2}$ exchange to sunlight varies with cloud cover as clouds alter the direction of incoming sunlight and how it penetrates into a canopy. The response of canopy-scale $\mathrm{CO}_{2}$ exchange to temperature is sensitive to the local climate. The temperature optima for canopy photosynthesis are different for similar functional forest types in Europe and North America.

\section{Future plans}

The presence of sites on less than ideal terrain affords the micrometeorological community to take the challenge and assess the impact of advection on the measurement of long-term fluxes. Given the current tower site distribution, there is a need to develop transect studies at anchor sites, so we can study spatial patterns in greater detail and better assess the impact of forest stand age, biodiversity, and land disturbances. Aircraft flux studies can be used to augment and extrapolate tower information in the spatial domain. More physiological and stand structure studies will be needed to aid in the interpretation of tower measurements and to provide contextual information to test ecophysiological models.

As data accumulate, new questions are arising about how to interpret fluxes made over mixed stands. Frontal passages cause the annual sums of ecosystem $\mathrm{CO}_{2}$ exchange to be biased, as associated changes in wind direction and speed cause a tower site to view a different flux footprint (Amiro 1998) or expose the ecosystem to different temperature and humidity regimes. Over sites with inadequate fetch or mixed vegetation in the flux footprint, flux densities that are measured will vary with wind direction. As knowledge evolves we may have to evaluate annual sums by weighting field measurements on the basis of wind direction and the appropriate flux footprint probability density functions (Schmid 1994). On the flip side, we can use information from different wind directions to address questions relating to the role of biodiversity on mass and energy exchange of ecosystems.

Acknowledgments. The FLUXNET project office and Data Archive is sponsored by NASA's EOS Validation Program. The component regional networks and individual field sites are sponsored by an array of government agencies. The Americas network, AmeriFlux, is sponsored by the United States Departments of Energy [Terrestrial Carbon Program, National Institutes of Global Environmental Change (NIGEC)], Commerce (NOAA), and Agriculture (USDA/Forest Service), NASA, the National Science Foundation, and the Smithsonian Institution. These federal agencies sponsor the Global Change Research Program (USGCRP) to promote cooperation with each other, academia, and the international community, in order to make it as easy as possible for researchers and others to access and use global change data and information.

European sites in the Euroflux and Medeflu projects are supported by the European Commission Directorate General XII Environment and Climate Program. Canadian collaborators are sponsored by the Natural Sciences and Engineering Research Council of Canada (NSERC). Japanese and Asian sites are supported by the Ministry of Agriculture, Forest and Fisheries (MAFF), the Ministry of Industrial Trade and Industry (MITI), and Ministry of Education, Science, Sports and Culture (MESSC).

We thank the numerous scientists, students, and technicians responsible for the day-to-day gathering of the flux data, and the agency representatives who fund the respective projects. Without the dedicated efforts of so many individuals, this global network would not function or exist. Special appreciation is extended to Drs. Roger Dahlman, Diane Wickland, Ruth Reck, and David Starr, who have provided funds that supported initial planning workshops and that support many of the operating science teams. 


\section{References}

Amiro, B. D., 1998: Footprint climatologies for evapotranspiration in a boreal catchment. Agric. For. Meteor., 90, 195 201.

— J. I. MacPherson, and R. L. Desjardins, 1999: BOREAS flight measurements of forest-fire effects on carbon dioxide and energy fluxes. Agric. For. Meteor., 96, 199-208.

Amthor, J. S., 1995: Terrestrial higher-plant response to increasing atmospheric $\left[\mathrm{CO}_{2}\right]$ in relation to the global carbon cycle. Global Change Biol., 1, 243-274.

Amundson, R., L. Stern, T. Raisden, and Y. Wang, 1998: The isotopic composition of soil and soil-respired $\mathrm{CO}_{2}$. Geoderma, 82, 83-114.

Anderson, D. E., S. B. Verma, and N. J. Rosenberg, 1984: Eddy correlation measurements of $\mathrm{CO}_{2}$, latent heat and sensible heat fluxes over a crop surface. Bound.-Layer Meteor., 29, 167183.

Anthoni, P. M., B. E. Law, and M. H. Unsworth, 1999: Carbon and water vapor exchange of an open-canopied ponderosa pine ecosystem. Agric. For. Meteor., 95, 115-168.

Aubinet, M., and Coauthors, 2000: Estimates of the annual net carbon and water exchange of Europeran forests: The EUROFLUX methodology. Adv. Ecol. Res., 30, 113-175.

BAHC Core Project Office, Eds., 1993: Biospheric aspects of the hydrological cycle. The operational plan. IGBP Rep. 27, Stockholm, Sweden, 103 pp.

Bakwin, P. S., P. P. Tans, D. F. Hurst, and C. L. Zhao, 1998: Measurements of carbon dioxide on very tall towers: Results of the NOAA/CMDL program. Tellus, 50B, 401-415.

Baldocchi, D. D., and T. P. Meyers, 1998: On using eco-physiological, micrometeorological and biogeochemical theory to evaluate carbon dioxide, water vapor and gaseous deposition fluxes over vegetation. Agric. For. Meteor., 90, 1-26.

— B. B. Hicks, and T. P. Meyers, 1988: Measuring biosphereatmosphere exchanges of biologically related gases with micrometeorological methods. Ecology, 69, 1331-1340.

_- R. Valentini, S. R. Running, W. Oechel, and R. Dahlman, 1996: Strategies for measuring and modeling $\mathrm{CO}_{2}$ and water vapor fluxes over terrestrial ecosystems. Global Change Biol., 2, 159-168.

— J. J. Finnigan, K. W. Wilson, K. T. Paw U, and E. Falge, 2000: On measuring net ecosystem carbon exchange in complex terrain over tall vegetation. Bound.-Layer Meteor., 96, 257-291.

_ E. Falge, and K. Wilson, 2001: A spectral analysis of biosphere-atmosphere trace gas flux densities and meteorological variables across hour to multi-year time scales. Agric. For. Meteor., 107, 1-27.

Barr, A. G., G. van der Kamp, R. Schmidt, and T. A. Black, 2000: Monitoring the moisture balance of a boreal aspen forest using a deep groundwater piezometer. Agric. For. Meteor., 102, 13-24.

Baumgartner, A., 1969: Meteorological approach to the exchange of $\mathrm{CO}_{2}$ between atmosphere and vegetation, particularly forests stands. Photosynthetica, 3, 127-149.

Berbigier, P., J.-M. Bonnefond, and P. Mellman, 2001: $\mathrm{CO}_{2}$ and water vapour fluxes for 2 years above Euroflux forest site. Agric. For. Meteor., 108, 183-197.
Betts, A. K., J. H. Ball, A. C. Beljaars, M. J. Miller, and P. A. Viterbo, 1996: The land surface-atmosphere interaction: A review based on observational and global modeling perspectives. J. Geophys. Res., 101, 7209-7225.

Black, T. A., and Coauthors, 1996: Annual cycles of $\mathrm{CO}_{2}$ and water vapor fluxes above and within a Boreal aspen stand. Global Change Biol., 2, 219-230.

- W. J. Chen, A. G. Barr, M. A. Arain, Z. Chen, Z. Nesic, E. H. Hogg, H. H. Neumann, and P. C. Yang, 2000: Increased carbon sequestration by a boreal deciduous forest in years with a warm spring. Geophys. Res. Lett., 27, 1271-1274.

Canadell, J., and Coauthors, 2000: Carbon metabolism of the terrestrial biosphere. Ecosystems, 3, 115-130.

Ceulemans, R., and M. Mousseau, 1994: Tansley Review No. 71. Effects of elevated atmospheric $\mathrm{CO}_{2}$ on woody plants. New Phytol., 127, 425-446.

Ciais, P., P. P. Tans, M. Trolier, J. W. C. White, and R. J. Francy, 1995: A large North Hemisphere terrestrial $\mathrm{CO}_{2}$ sink indicated by the ${ }^{13} \mathrm{C}^{12} \mathrm{C}$ ratio of atmospheric $\mathrm{CO}_{2}$. Science, 269, 1098-1102.

Clark, K. L., H. L. Gholtz, J. B. Moncrieff, F. Cropley, and H. W. Loescher, 1999: Environmental controls over net exchanges of carbon dioxide from contrasting Florida ecosystems. Ecological Appl., 9, 936-948.

Conway, T. J., P. P. Tans, L. S. Waterman, K. W. Thoning, D. R. Kitzis, K. Masarie, and N. Zhang, 1994: Evidence for interannual variability of the carbon cycle from NOAA/CMDL global sampling network. J. Geophys. Res., 99, 22 831-22 855.

Cramer, W. J., D. W. Kicklighter, A. Bondeau, B. Moore III, G. Churkina, B. Nemry, A. Ruimy, and A. L. Schloss, 1999: Comparing global models of terrestrial primary productivity (NPP): Overview and key results. Global Change Biol., 5, 1-15.

Crawford, T. L., R. J. Dobosy, R. T. McMillen, C. A. Vogel, and B. B. Hicks, 1996: Air-surface exchange measurement in heterogeneous regions: Extending tower observations with spatial structure observed from small aircraft. Global Change Biol., 2, 275-285.

Denmead, O. T., 1969: Comparative micrometeorology of a wheat field and a forest of Pinus radiata. Agric. For. Meteor., 6, 357-371.

—, M. R. Raupach, F. X. Dunin, H. A. Cleugh, and R. Leuning, 1996: Boundary layer budgets for regional estimates of scalar fluxes. Global Change Biol., 2, 255-264.

Denning, A. S., J. G. Collatz, C. Zhang, D. A. Randall, J. A. Berry, P. J. Sellers, G. D. Colello, and D. A. Dazlich, 1996: Simulations of terrestrial carbon metabolism and atmospheric $\mathrm{CO}_{2}$ in a general circulation model. Part 1: Surface carbon fluxes. Tellus, 48B, 521-542.

Desjardins, R. L., D. J. Buckley, and G. St. Amour, 1984: Eddy flux measurements of $\mathrm{CO}_{2}$ above corn using a microcomputer system. Agric. Meteor., 32, 257-265.

- , and Coauthors, 1997: Scaling up flux measurements for the boreal forest using aircraft-tower combinations. J. Geophys. Res., 102, 29 125-29 134.

Drake, B. G., M. A. Gonzalez-Meler, and S. P. Long, 1996: More efficient plants: A consequence of rising atmospheric $\mathrm{CO}_{2}$ ? Annu. Rev. Plant Physiol. Plant Mol. Biol., 48, 609-639.

Falge, E., and Coauthors, 2001: Gap filling strategies for defensible annual sums of net ecosystem exchange. Agric. For. Meteor., 107, 43-69. 
Fan, S. M., M. Gloor, J. Mahlman, S. Pacala, J. Sarmiento, T. Takahashi, and P. Tans, 1998: A large terrestrial carbon sink in North America implied by atmospheric and oceanic carbon dioxide data and models. Science, 282, 442-446.

Finnigan, J. J., 1999: A comment on the paper by Lee (1998): "On micrometeorological observations of surface-air exchange over tall vegetation." Agric. For. Meteor., 97, 55-64.

Foken, T., and B. Wichura, 1996: Tools for quality assessment of surface-based flux measurements. Agric. For. Meteor., 78, 83-105.

Foley, J. A., S. Levis, I. C. Prentice, D. Pollard, and S. L. Thompson, 1998: Coupling dynamic models of climate and vegetation. Global Change Biol., 4, 561-580.

Goldstein, A. H., and Coauthors, 2000: Effects of climate variability on the carbon dioxide, water, and sensible heat fluxes above a ponderosa pine plantation in the Sierra Nevada (CA). Agric. For. Meteor., 101, 113-129.

Goulden, M. L., J. W. Munger, S. M. Fan, B. C. Daube, and S. C. Wofsy, 1996a: Measurement of carbon storage by long-term eddy correlation: Methods and a critical assessment of accuracy. Global Change Biol., 2, 169-182.

$-, \ldots, \ldots$, and $\_, 1996 \mathrm{~b}$ : Exchange of carbon dioxide by a deciduous forest: Response to interannual climate variability. Science, 271, 1576-1578.

_ ance to soil thaw. Science, 279, 214-217.

Gower, S. T., C. J. Kucharik, and J. M. Norman, 1999: Direct and indirect estimation of leaf area index, fpar and net primary production of terrestrial ecosystems. Remote Sens. Environ., 70, 29-51.

Granier, A., E. Ceschia, and C. Damesin, 2000: The carbon balance of a young beech forest. Funct. Ecol., 14, 312-325.

Greco, S., and D. D. Baldocchi, 1996: Seasonal variations of $\mathrm{CO}_{2}$ and water vapor exchange rates over a temperate deciduous forest. Global Change Biol., 2, 183-198.

Gu, L., J. D. Fuentes, H. H. Shugart, R. M. Staebler, and T. A. Black, 1999: Responses of net ecosystem exchanges of carbon dioxide to changes in cloudiness: Results from two North American deciduous forests. J. Geophys. Res., 104, 31 42131434.

Halldin, S., S. E. Gryning, L. Gottschalk, A. Jochum, L.-C. Lundin, and A. A. Van de Griend, 1999: Energy, water and carbon exchange in a boreal forest landscape-NOPEX experiences. Agric. For. Meteor., 98-99, 5-29.

Hanson, J. E., M. Sato, A. Lacias, R. Ruedy, I. Tegen, and E. Matthews, 1998: Climate forcings in the industrial era. Proc. Natl. Acad. Sci. USA. 95, 12 753-12 758.

Hollinger, D.Y., S. M. Goltz, E. A. Davidson, J. T. Lee, K. Tu, and H. T. Valentine, 1999: Seasonal patterns and environmental control of carbon dioxide and water vapor exchange in an ecotonal boreal forest. Global Change Biol., 5, 891-902.

Houghton, R. A., and G. Woodwell, 1980: The flax pond ecosystem study: Exchanges of $\mathrm{CO}_{2}$ between a salt marsh and the atmosphere. Ecology, 61, 1434-1445.

Inoue, I., 1958: An aerodynamic measurement of photosynthesis over a paddy field. Proc. Seventh Japan National Congress of Applied Mechanics, 211-214.

Jacobs, C. M. J., and H. A. R. De Bruin, 1992: The sensitivity of transpiration to land-surface characteristics: Significance of feedback. J. Climate, 5, 683-698.
Jarvis, P. G., G. B. James, and J. J. Landsberg, 1976: Coniferous forest. Vegetation and the Atmosphere, J. L. Monteith, Ed., Vol. 2, Academic Press, 171-240.

Kaimal, J. C., and J. J. Finnigan, 1994: Atmospheric Boundary Layer Flows: Their Structure and Measurement. Oxford University Press, 289 pp.

Kauppi, P. E., K. Mielikainen, and K. Kuuseia, 1992: Biomass and carbon budget of European forests, 1971 to 1990. Science, 256, 70-74.

Keeling, C. D., and T. P. Whorf, 1994: Atmospheric $\mathrm{CO}_{2}$ records from sites in the SIO air sampling network. Trends '93: A compendium of data on global change. Oak Ridge National Laboratory Rep. ORNL/CDIAC-65, 16-26.

,$- \ldots$, M. Wahlen, and J. van der Plicht, 1995: Interannual extremes in the rate of rise of atmospheric carbon dioxide since 1980. Nature, 375, 666-670.

_ S. C. Piper, and M. Heimann, 1996: Global and hemispheric $\mathrm{CO}_{2}$ sinks deduced from changes in atmospheric $\mathrm{O}_{2}$ concentration. Nature, 381, 218-221.

Kelliher, F. M., R. Leuning, M. R. Raupach, and E. D. Schulze, 1995: Maximum conductances for evaporation from global vegetation types. Agric. For. Meteor., 73, 1-16.

Law, B. E., A. H. Goldstein, P. M. Anthoni, J. A. Panek, M. H. Unsworth, M. R. Bauer, J. M. Fracheboud, and N. Hultman, 2000: $\mathrm{CO}_{2}$ and water vapor exchange by young and old ponderosa pine ecosystems during a dry summer. Tree Physiol., 21, 299-308.

Lee, X., 1998: On micrometeorological observations of surfaceair exchange over tall vegetation. Agric. For. Meteor., 91, $39-50$

_ J. D. Fuentes, R. M. Staebler, and H. H. Neumann, 1999: Long-term observation of the atmospheric exchange of $\mathrm{CO}_{2}$ with a temperate deciduous forest in southern Ontario, Canada. J. Geophys. Res., 104, 15 975-15984.

Lemon, E. R., 1960: Photosynthesis under field conditions. II. An aerodynamic method for determining the turbulent carbon dioxide exchange between the atmosphere and a corn field. Agron. J., 52, 697-703.

Levy, P. E., A. Grelle, A. Lindroth, M. Molder, P. G. Jarvis, B. Kruijt, and J. B. Moncrieff, 1999: Regional scale CO fluxes over central Sweden by a boundary layer budget method. Agric. For. Meteor, 98-99, 169-180.

Lindroth, A., A. Grelle, and A. S. Moren, 1998: Long-term measurements of boreal forest carbon balance reveal large temperature sensitivity. Global Change Biol., 4, 443-450.

Malhi, Y., A. D. Nobre, J. Grace, B. Kruijt, M. Pereira, A. Culf, and S. Scott, 1998: Carbon dioxide transfer over a central Amazonian rain forest. J. Geophys. Res., 103, 31 593-31 612.

—, D. D. Baldocchi, and P. G. Jarvis, 1999: The carbon balance of tropical, temperate and boreal forests. Plant, Cell and Environ., 22, 715-740.

Markkanen, T., U. Rannik, P. Keronen, T. Suni, and T. Vesala, 2001: Eddy covariance fluxes over a boreal Scots pine forest. Boreal Environ. Res., 6, 65-78.

Massman, W. J., 2000: A simple method for estimating frequency response corrections for eddy covariance systems. Agric. For. Meteor., 104, 185-198.

Meyers, T. P., 2001: A comparison of summertime water and $\mathrm{CO}_{2}$ fluxes over rangeland for well-watered and drought conditions. Agric. For. Meteor., 106, 205-214. 
Moncrieff, J. B., Y. Mahli, and R. Leuning, 1996: The propagation of errors in long term measurements of land atmosphere fluxes of carbon and water. Global Change Biol., 2, 231-240.

Monteith, J. L., and G. Szeicz, 1960: The $\mathrm{CO}_{2}$ flux over a field of sugar beets. Quart. J. Roy. Meteor. Soc., 86, 205-214.

Moore, C. J., 1986: Frequency response corrections for eddy covariance systems. Bound-Layer Meteor., 37, 17-35.

Myneni, R. B., C. D. Keeling, C. J. Tucker, G. Asrar, and R. R. Nemani, 1997a: Increased plant growth in the northern high latitudes from 1981-1991. Nature, 386, 698-702.

— global leaf area index and absorbed par using radiative transfer models. IEEE Trans. Geosci. Remote Sens., 35, 13801393.

Niinemets, U., V. Oja, and O. Kull, 1999: Shape of leaf photosynthetic electron transport versus temperature response curve is not constant along canopy light gradients in temperate deciduous trees. Plant, Cell Environ., 22, 1497-1513.

Norby, R. J., S. D. Wullschleger, C. A. Gunderson, D. W. Johnson, and R. Ceulemans, 1999: Tree responses to rising $\mathrm{CO}_{2}$ in field experiments: Implication for the future forest. Plant, Cell Environ., 22, 683-714.

Oechel, W. C., G. L. Vourlitis, S. J. Hastings, R. C. Zulueta, L. Hinzman, and D. Kane, 2000: Acclimation of ecosystem $\mathrm{CO}_{2}$ exchange in the Alaskan Arctic in response to decadal climate warming. Nature, 406, 978-981.

Ohtaki, E., 1984: Application of an infrared carbon dioxide and humidity instrument to studies of turbulent transport. Bound.Layer Meteor., 29, 85-107.

Pielke, R. A., R. Avissar, M. Raupach, A. J. Dolman, X. Zeng, and A. S. Denning, 1998: Interactions between the atmosphere and terrestrial ecosystems: Influence on weather and climate. Global Change Biol., 4, 461-475.

Pilegaard, K., P. Hunnelshøj, N. O. Jensen, and Z. Chen, 2001: Two years of continuous $\mathrm{CO}_{2}$ eddy-flux measurements over a Danish beech forest. Agric. For. Meteor., 107, 29-41.

Potosnak, M. J., S. C. Wofsy, A. S. Denning, T. J. Conway, J. W. Munger, and D. H. Barnes, 1999: Influence of biotic exchange and combustion sources on atmospheric $\mathrm{CO}_{2}$ concentrations in New England from observations at a forests flux tower. $J$. Geophys. Res., 104, 9561-9569.

Randerson, J. T., M. V. Thompson, T. J. Conway, I. Y. Fung, and C. B. Field, 1997: The contribution of terrestrial sources and sinks to trends in the seasonal cycle of atmospheric carbon dioxide. Global Biogeochem. Cycles, 11, 535-560.

Raupach, M. R., and B. J. Legg, 1984: The uses and limitations of flux-gradient relationships in micrometeorology. Agric. Water Manage., 8, 119-131.

Ruimy, A., P. G. Jarvis, D. D. Baldocchi, and B. Saugier, 1995: $\mathrm{CO}_{2}$ fluxes over plant canopies and solar radiation: A review. Adv. Ecol. Res., 26, 1-53.

Running, S. W., D. D. Baldocchi, D. Turner, S. T. Gower, P. Bakwin, and K. Hibbard, 1999: A global terrestrial monitoring network, scaling tower fluxes with ecosystem modeling and EOS satellite data. Remote Sens. Environ., 70, 108127.

Schmid, H. P., 1994: Source areas for scalars and scalar fluxes. Bound.-Layer Meteor., 67, 293-318.
C. S. Grimmond, F. Cropley, B. Offerle, and H.-B. Su, 2000: Measurements of $\mathrm{CO}_{2}$ and energy fluxes over a mixed hardwood forest in the mid-western United States. Agric. For. Meteor., 103, 357-374.

Schulze, E. D., and Coauthors, 1999: Productivity of forests in the Eurosiberian boreal region and their potential to act as a carbon sink-A synthesis. Global Change Biol., 5, 703722 .

Schwartz, M. D., 1996: Examining the spring discontinuity in daily temperature ranges. J. Climate, 9, 803-808.

Sellers, P. J., and Coauthors, 1997: BOREAS in 1997: Scientific results, experimental overview and future directions. $J$. Geophys. Res., 102, 28 731-28 770.

Suyker, A. E., and S. B. Verma, 2001: Year-round observations of the net ecosystem exchange of carbon dioxide in a native tall grass prairie. Global Change Biol., 3, 279-290.

Tans, P. P., I. Y. Fung, and T. Takahashi, 1990: Observational constraints on the global atmospheric $\mathrm{CO}_{2}$ budget. Science, 247, 1431-1438.

Valentini, R., P. de Angelis, G. Matteucci, R. Monaco, S. Dore, and G. E. Scarascia-Mugnozza, 1996: Seasonal net carbon dioxide exchange of a beech forest with the atmosphere. Global Change Biol., 2, 199-208.

, G. Matteucci, and A. J. Dolman, 2000: Respiration as the main determinant of carbon balance in European forests. $\mathrm{Na}$ ture, 404, 861-864.

Verma, S. B., D. D. Baldocchi, D. E. Anderson, D. R. Matt, and R. E. Clement, 1986: Eddy fluxes of $\mathrm{CO}_{2}$ water vapor, and sensible heat over a deciduous forest. Bound.-Layer Meteor., 36, 71-91.

_, J. Kim, and R. J. Clement, 1989: Carbon dioxide, water vapor and sensible heat fluxes over a tall grass prairie. Bound.-Layer Meteor., 46, 53-67.

Vermetten, A. W. M., L. Ganzeveld, A. Jeuken, P. Hofschreuder, and G. M. J. Mohren, 1994: $\mathrm{CO}_{2}$ uptake by a stand of Douglas fir: Flux measurements compared with model calculations. Agric. For. Meteor., 72, 57-80.

Wilson, K. B., and D. D. Baldocchi, 2000: Esimating annual net ecosystem exchange of carbon over five years at a deciduous forest in the southern United States. Agric. For. Meteor., 100, $1-18$.

- - - and P. J. Hanson, 2000: Spatial and seasonal variability of photosynthesis parameters and their relationship to leaf nitrogen in a deciduous forest. Tree Physiol., 20, 787797.

Wofsy, S. C., M. L. Goulden, J. W. Munger, S. M. Fan, P. S. Bakwin, B. C. Daube, S. L. Bassow, and F. A. Bazzaz, 1993: Net exchange of $\mathrm{CO}_{2}$ in a mid-latitude forest. Science, $\mathbf{2 6 0}$, 1314-1317.

Yamamoto, S., S. Murayama, N. Saigusa, and H. Kondo, 1999: Seasonal and interannual variation of $\mathrm{CO}_{2}$ flux between a temperate forest and the atmosphere in Japan. Tellus, 51B, 402413.

Yi, C., K. J. Davis, P. S. Bakwin, B. W. Berger, and L. C. Marr, 2000: Influence of advection on measurements of the net ecosystem-atmosphere exchange of $\mathrm{CO}_{2}$ from a very tall tower. J. Geophys. Res., 105, 9991-9999. 